\section{MONUMENTS OF THE LATE ROMAN PERIOD - EARLY GREAT MIGRATION PERIOD IN THE DNIEPER-DONETS FOREST- STEPPE: MAIN RESULTS AND METHODOLOGICAL ISSUES}

\begin{abstract}
The subject of publication was to assess the level of research of monuments of different cultural groups and to define main studying problems of the region of the Late Roman Period - erly Great Migration Period. Two main concepts of ethno-cultural development of the region at this time. According to first Chernyakhov Culture here appears in a mid- $3^{\text {rd }}$ century $\mathrm{AD}$, and there before early $5^{\text {th }}$ century $\mathrm{AD}$. According to another in the middle of the $3^{\text {rd }}$ early $4^{\text {th }}$ centuries. $\mathrm{AD}$ in the region existed early-slavic monuments ("horizon Boromlya") and Chernyahkiv Culture - in the second quarter of the $4^{\text {th }}$ - early $5^{\text {th }}$ centuries $\mathrm{AD}$. Recently, the most convincing is the second hypothesis: the Roman coin finds in the region support this thesis.
\end{abstract}

Keywords: Dnieper-Donets forest-steppe, horizon Boromlya, Chernyakhov Culture, ancient coins

$\mathbf{A}$ rest-steppe region between the Dnieper and Seversky Donets forms a fairly large geographical area in Eastern Europe. In the mid I - middle V century BC this area was a part of Barbaricum in the conditions of existence of the Roman Empire and its contacts with the local barbaric population (Fig. 1).

For us this area in this period is in the "early history" stage (Frühgeschichte): scanty information about it is preserved in the works of ancient authors, but there are quite extensive archaeological sources.

\section{History of the study of monuments}

Monuments of mid $3^{\text {rd }}$ - early $4^{\text {th }}$ centuries. The case is about settlements (burials and burial grounds of this time aren't known) that existed in the period from the final postzarubinets horizon (about the first half - mid- $3^{\text {rd }}$ century) until "classical" Chernyakhov Culture (early - the first quarter of the $4^{\text {th }}$ century) (Fig. 2). These monuments form a cultural and chronological horizon («horizon of Boromlia» according to M.B. Shukin and M.V. Liubichev) ${ }^{1}$ with such chronological indicators as: fibulae with high receiver of group VII Almgren, bow fibulae Almgren 157, light-coloured clay amphorae Shelov D («Tanais» tip), with absolute predominance of moulded ceramics and minor

\section{Michail Liubichev Kirill Myzgin \\ State University 'V.N. Karazin' Kharkiv gsae@mail.ru; myzgin@mail.ru}

DOI: http://dx.doi.org/10.14795/j.v1i3.61

ISSN $2360-266 \mathrm{X}$

ISSN-L $2360-266 X$

\footnotetext{
SHUKIN 2005, 133; LIUBICHEV 2008a, 51.
} 
amount of pottery, the presence of depressed constructions in the settlements (Figs. 2-5). Quite often such settlements are covered by settlements of "classical" Chernyakhov Culture.

In 1949, E.V. Makhno explored Besedovka settlement, where the remains of above-ground wattle and daub constructions of Chernyakhov Culture located in the layer above the fragments of pottery. Here the narrow-necked light-coloured amphora Shelov D was discovered ${ }^{2}$. In 19781979, in the settlement of Bukreevka 2 E.A. Symonovich studied the remains of nine buildings ${ }^{3}$.

In 1982, in the settlement of Mamroi 2 E.N. Petrenko found a depressed construction and a pit. Moulded ceramics concentrated near the floor of the construction, pottery got there after the destruction of the construction ${ }^{4}$. The building was destroyed by fire, the remains of above-ground wattle and daub structure located above it. In 1984 Yu.V. Buinov studied two half-dugouts and one hole in the settlement of Rodnoi Krai $3^{5}$. In 1987-1991 V.M. Goryunova and O.A. Scheglova conducted research in the settlements of Gochevo 3 and Gochevo 4 with the horizon of Boromlia and "classical" Chernyakhov Culture $^{6}$.

In 1987-1991, A.N. Nekrasova and R.V. Terpilovskiy studied the settlement of Boromlia 2 (Nekrasova, 2006) (Fig.3), where four buildings of early horizon were referred by us to the horizon of Boromlia ${ }^{7}$. In 1988-1989 A.M. Oblomskiy studied the settlement of Golovino $1^{8}$, where he also observed the presence of the horizon of Boromlia and "classical" Chernyakhov Culture. In 1990, A.I. Zhurko in the Peschanoe settlement (Psiol) studied, among other things, objects of the horizon of Boromlia, including those covered with the remains of above-ground wattle and daub structure of Chernyakhov Culture ${ }^{9}$. In 1994, in the 10th of October settlement, A.M. Oblomskiy opened two depressed structures with moulded ceramics and pottery, fragments of amphorae Shelov D. In the layer there were also findings of stage C3 items ${ }^{10}$.

Since 2004 Germanic-Slavonic archaeological expedition of V.N. Karazin Kharkiv National University has been conducting excavations of archaeological complex Voytenki 1. Conditionally closed complexes, findings in the layer and lifted material relating to the steps $\mathrm{C} 1 \mathrm{~b}, \mathrm{C} 2$ (horizon of Boromlia) are present only in the area "A" of the settlement, covered with the horizon of Chernyakhov Culture $^{11}$ (Figs. 4, 5). In 2007-2008 K.V. Myzgin studied Ogul'tsy settlement with the findings dated to the stages $\mathrm{C} 1 \mathrm{~b}, \mathrm{C2}$ and distinctive moulded ceramics (horizon of Boromlia), along with findings specific to closed complexes of stages C3 and C3/D1 (Chernyakhov Culture) ${ }^{12}$.

It the settlement of Gochevo 1 that was studied by N.A. Tikhomirov, R.V. Terpilovskiy in 1986-1987 one

\footnotetext{
MAKHNO 1955, 82, 84, ris. 5: 9.

SYMONOVICH 1990.

4 PETRENKO 1983, 13-15.

BASHKATOV/DEGTIAR'/LIUBICHEV 1997.

6 OBLOMSKIY 2002, 33-34; PAMYATNIKI... 2007, 91-93.

LIUBICHEV 2013, 14.

8 OBLOMSKIY 2001-2002.

ZHURKO 1994, 215-217.

10 OBLOMSKIY 2002, 37-38.

1 LIUBICHEV 2006, 2008b; LJUBIČEV 2006.

12 MYZGIN 2011b.
}

building is referred to mid 3rd - early 4 th centuries ${ }^{13}$, and two buildings in the settlement of Gochevo $2^{14}$. Yu.A. Lipking pitting Novosiolovka settlement (Sudzha River) found fragments of molded ceramics and pottery, and also the fibula of group VII O. Almgren ${ }^{15}$.

Thus, we now know more than a dozen settlements of that time, where excavations were held.

Chernyakhov Culture. Monuments of Chernyakhov Culture have the longest history of studying (Fig. 6). Since $19^{\text {th }}-20^{\text {th }}$ centuries until the 20 's of the $20^{\text {th }}$ century occurred: a) admission of separate things from the surface of Chernyakhiv monuments and destroyed burials to museums (Kursk gubernia, Grechaniki, Belotserkovtsy, Savinki, Konstantinograd, Proni, Shyshaki); b) search for analogies of things from Late Sarmatian undermounded burials among eponymous collection of Chernyakhiv and Romashki burial grounds; c) fixing the traces of settlements on the places where hoards of Roman coins were found (Gridasovka) ${ }^{16}$.

The 20's-30's of the 20th century were the time of introduction of the region's material to the areal of "burial ground" culture, conducting exploration, excavations of monuments and constructing first archaeological maps. To this time refer the opening of Chernyakhiv monuments by explorations of L. Soloviov (Vorskla, Udy revers) ${ }^{17}$, E.N. Antonovich-Mel'nik (Orel River) ${ }^{18}$, N.D. Renskiy (Sula River $^{19}$, A.S. Fedorovskiy, I.N. Lutskevich (Mzha, Lopan', Kharkiv, Severskiy Donets rivers) ${ }^{20}$. During this period a few excavations of Cherniakhov monuments were conducted: Gurbincy burial ground ${ }^{21}$, Peresechnaya settlement and burial ground ${ }^{22}$, the burial at Vodiane (A.V. Dobrovol'skiy) ${ }^{23}$, Svinkovka burial ground ${ }^{24}$, Novosiolovka burial ground (N.A. Stan, N.D. Sych) ${ }^{25}$. By 1941, I.N. Lutskevich had prepared a set of Cherniakhov monuments and some Late Sarmatian undermounded burials in the upper reaches of the Vorskla and the Seversky Donets, which was published in succinct format in $1948^{26}$.

After 1945 a new stage of the study begins, characterized by dramatically increasing volume of field work, number of monuments opened by exploration and studied by excavations, publications, appearance of conceptual developments. Since the mid-20th century appeared cartographic catalogues of Chernyakhiv monuments of the whole region ${ }^{27}$ or its parts ${ }^{28}$. Given the amount of sources, the history of research of Chernyakhiv monuments at this time it is reasonable to consider six selected for main rivers'

\footnotetext{
13 TIKHOMIROV/TERPILOVSKIY 1990, 43.

14 TIKHOMIROV/TERPILOVSKIY 1990, 60-63, ris. 11.

OBLOMSKIY 1991, 15, ris. 3:1.

6 LIUBICHEV 2000, 9-15; SYMONOVICH 1964, ris. 4: 6-8, 1983, ris. 1: 1,

2, 4; RUDINTSKIY 1928, 51-52.

7 LUTSKEVICH 1948, 165.

8 ANTONOVICH-MEL'NIK 1926.

9 GEIKO/REIDA/MILASCHEVSKYI 2011.

20 LUTSKEVICH 1948, 165, 167-168, 169-170.

MAKARENKO 1927, 112.

22 LUTSKEVICH 1948, 165-168.

3 SYMONOVICH/KRAVCHENKO 1983, 68.

LYAPUSHKIN 1961, 172.

MAKHNO 1960, 41; STEPANOVICH/SUPRUNENKO 1994, 23-24.

LUTSKEVICH 1948.

LYAPUSHKIN 1950, map; 1961, 159-180, ris. 81; MAKHNO 1960, 31-32, $37-43,44-46,49-51,56,62-63$, ris. 1

28 SYMONOVICH 1964, 23, 1983, 73; DIACHENKO 1980.
} 
basins areas (Fig. 6$)^{29}$.

In the area of "Dnieper, the coastal part of the left bank" by excavations studied such settlements as Barbara ${ }^{30}$, Gradizhsk (Krucha stow), Zhovnin (Vasilenki stow) ${ }^{31}$, Erkovtsy $^{32}$, Meksimovka, Novolipovskoe, Radutskovka ${ }^{33}$, Sosnova ${ }^{34}$, Khlopkov $1^{35}$, burial grounds of Gradizhsk (Krucha stow) $^{36}$, Zhovnin (Bilenkovy Burty, Nosenki, Pristan' stows $^{37}$, Kompaniytsy ${ }^{38}$, Pereyaslav-Khmen'nitskiy ${ }^{39}$, Sosnova ${ }^{40}$.

In the area of "Desna-Seim" were studied settlements of Belopol'e $1^{41}$, Desiatyi Oktyabr' ${ }^{32}$, Kolosovka ${ }^{43}$, Lipovka $1^{44}$, Snagost' $2^{45}$. The study of Peny settlement is in progress ${ }^{46}$. Only one burial ground is covered with excavations - Peny $3^{47}$.

In the area of "Sula" were excavated such settlements: Artiukhovka $1^{48}$, Besedovka, Korovintsy ${ }^{49}$, Gnidincy 6, Dubina 1, Savenkov Yar 1, Grabarovka 1, Davydovka ${ }^{50}$, burial grounds of Volchek ${ }^{51}$, Voskresenskoe 1, Dunina $1^{52}$, Lokhvitsa $^{53}$, Uspenka ${ }^{54}$.

In the area of "Psiol" were studied the settlements of Vasilenki $4^{55}$, Velikiy Bobrik, Kosovshina 1, Kosovshina 2, Krasnopol'e 1, Peschanoe ${ }^{56}$, Gochevo 3 Gochevo 457, Dmitrovka $3^{58}$, Mamroi $2^{59}$, burial grounds of Zamoshanskaya Diuna $^{60}$, Sumy ${ }^{61}$, Sumy-Sad ${ }^{62}$.

In the area of "Vorskla-Orel"' were studied settlements of Boromlia 2 (two of the three selected horizons refer to Chernyakhiv culture) ${ }^{63}$, Voytenki $1,2^{64}$, Voznesenskiy

\footnotetext{
29 LIUBICHEV 2013.

30 BASHKATOV 2010.

RUTKOVSKAYA 1979, 331-338.

DANILENKO/STOLAR 1952.

ABASHINA/OBLOMSKIY/TERPILOVSKIY 1999, 84-90.

MAKHNO/SIKORSKYI 1989.

NEKRASOVA 1988.

RUTKOVSKAYA 1979, 338.

RUTKOVSKAYA 1979, 317-328; PETRAUSKAS/TSINDROVSKAYA

2002; KRAKALO 2004.

38 MAKHNO 1971b; NEKRASOVA 2006.

39 GONCHAROV/MAKHNO 1957.

MAKHNO/SIKORSKIY 1989.

NEKRASOVA 1994.

NEKRASOVA 1994

SYMONOVICH 1983, 76-79.

TERPILOVSKIY 2008, 298.

SYMONOVICH/SOKOL 1978

RADIUSH 2010, 180-206.

RADIUSH 2010; RADIUSH 2011.

ROMANOVA 1989.

MAKHNO 1955.

LIUBICHEV 1999, 14-16.

KROPOTKIN 1969.

ZHAROV/TERPILOVSKIY 2011.

BEREZOVETS/PETROV 1960.

MAKHNO 1971a; NEKRASOVA 2006.

SUPRUNENKO/SHERSTYUK 2006, 28-30; 2007, 27-28.

ZHURKO 1994.

OBLOMSKIY 2002, 33-34.

BASHKATOV 2010.

OBLOMSKIY 2002, ris.59.

LIPKING 1979.

BOGUSEVICH 1960; MAKHNO 1967

2 NEKRASOVA 1985; SCHULTZE 2009.

NEKRASOVA 2006.

64 DIACHENKO 1976.
}

$1^{65}$, Golovshino ${ }^{66}$, Kantemirovka ${ }^{67}$, Lozovaya $2^{68}$, Starye Sanzhary ${ }^{69}$, burial grounds of Boromlia $1^{70}$, Kantemirovka ${ }^{71}$, Novosiolovka $^{72}$, Pavliukovka ${ }^{73}$, Pisarevka ${ }^{74}$, Zachepilovka ${ }^{75}$. Since 2004 studies of the settlement Voytenki 1 have been continued (Figs.7-9), and since 2005 annual studies have been conducted at the nearby burial ground (Figs. 10-15).

In the area of "Severskiy Dones" excavations were conducted in the settlements of Golovino $1^{76}$, Kolesniki, Tymchenki ${ }^{77}$, Murom $6^{78}$, Murom $7^{79}$, Novaya Pokrovka ${ }^{80}$, Novoberekskoe, Ogul'tsy ${ }^{81}$, Rodnoi Krai ${ }^{82}$, Khalimonovka, Shliakh $2^{83}$, Khokhlovo $2^{84}$, burial grounds of Glubokoe ${ }^{85}$, Golovino $1^{86}$, Rodnoi Krai 1, Sokolovo $2^{87}$.

We considered 902 monuments of Chernyakhov Culture. Of them 55 settlements and 29 burial grounds were studied by excavations of various size. 56 individual burials - parts of the burial grounds - were discovered by accident ${ }^{88}$. Undermounded burials with Chernyakhiv items. Represent a heterogeneous group of monuments, which in various extent combines features of the culture of the Sarmatians and Chernyakhov Culture. Some of these complexes are located in the areal of Chernyakhov Culture, in the zone of steppe - forest-steppe border (Kantemirovka, Storozhevoe) or even in the forest-steppe (Irzhevo). Another part is located outside the areal of culture, in the steppe zone (Mechebelovo, Vorontsovka, Dmukhailovka, Mospinskaia).

At the beginning of the $20^{\text {th }}$ century. V.A. Gorodtsov investigated burial ground 1 of the mound 4 near Mechebelovo ${ }^{89}$, and E. N. Mel'nik - burial in the mound 6 near Vorontsovka ${ }^{90}$. In 1924, M. Ya. Rudinskiy conducted excavations of three undermounded burials near Kantemirovka ${ }^{91}$ (Fig. 16: II). Until 1940 was found an undermounded burial near Irzhevo, documentation of the excavations is not preserved ${ }^{92}$.

In the 70's-80's, burials were investigated in the mound 13 near Dmukhailovka ${ }^{93}$ and in the mound 1 near Mospinskaia ${ }^{94}$. Since 2007 archaeologists of Poltava local

${ }_{65}$ KROPOTKIN/OBLOMS'KYI 1991, ris.2: 5.

66 OBLOMSKIY 2002, tabl.6.

67 MAKHNO 1952.

68 SKIRDA 2000; SKIRDA 2002.

69 GEIKO 1999.

NEKRASOVA 2006.

MAKHNO 1952, 236-240.

SYMONOVICH/KRAVCHENKO 1983, 68.

SHRAMKO 1979.

LYAPUSHKIN 1961, 171.

LIUBICHEV/MYZGIN, in print

OBLOMSKIY 2001-2002.

LIUBICHEV 2007.

SHRAMKO/DYACHENKO 1978

BERESTNEV/BUINOV/DIACHENKO/SHRAMKO 1979.

KUKHARENKO 1952, 43-46.

81 MYZGIN 2011a; MYZGIN $2011 \mathrm{~b}$.

82 BORODULIN 1975

3 LIUBICHEV 2005a.

4 OBLOMSKIY, 2002 Fig.57.

5 LIUBICHEV 2002.

6 OBLOMSKIY 2001-2002.

7 PETRENKO 1991.

88 LIUBICHEV 2013.

89 GORODTSOV 1905, 211.

90 MEL'NIK 1905, 726

91 RUDINSKIY 1930.

92 SYMONOVICH/KRAVCHENKO 1983, p. 66.

93 SHALOBUDOV/ANDROSOV/MUHOPAD 1983.

94 SIMONENKO 2012. 
history museum began studying mound burial of the Great Migration era near Storozhevoe ${ }^{95}$. In 2009 was investigated the inlet burial 5 of mound 2 near Lavrikovka ${ }^{96}$ (Fig.16: I).

Monuments of Kamenevo 2 - Komarovka 2 type. This group is represented only by settlements that were investigated in the 60 - 70ies of the last century. Yu.A. Lipking found villages of Vorobevka 2, Komarovka 2 E.A. Symonovich and O.N. Melnikova - settlements of Kamenevo 2 and Tazovo. EA Goriunov discovered and studied village of Peschanoe (1978-1979 gg. ${ }^{97}$. E.A. Symonovich conducted excavations in the settlements of Vorobyovka $2(1970)^{98}$, Komarovka $2(1972)^{99}$, Kamenevo 2 (1978) ${ }^{100}$, Tazovo $(1979)^{101}$.

\section{Main problem of cultural development}

History of formation of cultural development concepts of the region during the studied period may be divided into two periods depending on the sources condition.

The first period is conventionally limited by 19271980, the time when developed issues almost exclusively associated with Chernyakhov Culture (monuments mapping and determination of the areal boundary, attempts to determine the regional characteristics and ethnicity). In the late 1920's A.S. Fedorovskiy and A.A. Spitsyn on the basis of exploration data, admission of certain items to museums, presence of Sarmatian burials with Chernyakhiv items came to the conclusion that the area of forest-steppe from the Dnieper to the Severskiy Donets is a part of the "culture of burial grounds" (Chernyakhov Culture was called so at that time $)^{102}$. I.I. Liapushkin first mapped all known monuments of Chernyakhov Culture region ${ }^{103}$. They are also placed in the catalog and on the general map of Chernyakhov Culture monuments in Ukraine, performed by E.V. Makhno ${ }^{104}$. In the works of E.A. Smonovich was defined the border of the area of the culture in the north, in the basin of the Desna and the Sejm ${ }^{105}$.

Poor state of exploration of Chernyakhiv monuments in the 50's and the 70's of the last century produced opinion about their location here as "separate" islands ${ }^{106}$ or about the "zone of rare occurrence of Chernyakhiv monuments" in the area of the Left Bank to the upper reaches of the Seim and the Severskiy Donets, unlike the main territory of the culture from the Prut to Dnieper left bank ${ }^{107}$. E.V. Makhon drew a conclusion about the presence of Seim-Donets group of Chernyakhov Culture, adjoined to the core of the culture - to the Middle Dnieper region ${ }^{108}$. V.D. Baran singled out in Chernyakhov Culture a group of "forest-steppe zone of Ukraine", which is characterized by: a) preponderance of

\footnotetext{
95 KOVALENKO/LUGOVIY 2008.

96 SUPRUNENKO/LIAMKIN/SIDORENKO 2011.

97 GORIUNOV 1981.

98 SYMONOVICH 1974a; $1974 \mathrm{~b}$

99 MEL'NIKOVSKYA/SYMONOVICH 1975.

100 SYMONOVICH 2001-2002.

101 SYMONOVICH 1986.

102 FEDOROVSKIY 1927, 71; SPITSYN 1948, 69.

103 LIAPUSHKIN 1950, map; 1961, 159-180, ris. 81.

104 MAKHNO 1960, 31-32, 37-43, 44-46, 49-51, 61, ris.1.

105 SYMONOVICH 1964, 23, 1983, 73.

106 BRAICHEVS’KYI 1957, 14, 1964, 43-44.

107 GEI 1980, 35

108 MAKHNO 1970.
}

small and medium-sized settlements, depressed dwellings; b) equal proportions of cremations and burials at the burial grounds; c) absence of burial pits with lining; g) a small amount of pits with shoulders and crouched skeletons; d) moulded pots of slender proportions; e) absence of Scythian-Sarmatian forms of moulded vessels; g) small amount of imported antique ceramics; h) small part of moulded ceramics in above-ground dwellings ${ }^{109}$. It should be noted that the analysis of the sources, received over the last thirty years, indicates that this theoretical construct does not correspond to archaeological realities or need correction.

A.A. Spitsyn in the 20's of the XX century, given monuments of Kantemirovka and Vorontsovka type and adding them to a special group, believed that the burial rite and items of Chernyakhov Culture may be considered Late Sarmatian ${ }^{110}$. According to I.I. Liapushkin the ethnic composition of cultural monuments carrires in the region is composed of two elements: the Sarmatian (undermounded burials of Kantemirovka and Vorontsovka) and Slavonic ("burials close to the left bank side») $)^{111}$.

The second period began in the 80's. It is associated with increasing amount of studied monuments of Chernyakhov Culture itself, allocation of other cultural groups in the region, which preceded and were synchronous to Chernyakhov Culture. Great importance has increasing number of investigated monuments in all parts of Chernyakhov Culture areal/Santana de Mures Culture ${ }^{112}$, allocation of group of Chernyakhiv monuments of Demianov-Cherepin type in the Upper Dniester ${ }^{113}$. All this enabled with the necessary base of sources to solve the problem of occurrence of Chernyakhov Culture to the east of the Dnieper, to the problem of its contacts with other groups in this region.

In the early 1980's was allocated Kiev Culture of late $2^{\text {nd }}-$ early $5^{\text {th }}$ centuries for the Middle Dnieper and the Podesenie ${ }^{114}$. E.A. Symonovich was one of the first who drew attention to the close cooperation between Kiev and Chernyakhov Cultures, referred a number of settlements with prevailing moulded ceramics in Poseyme to Chernyakhiv, expressed the opinion about the appearance of Chernyakhov Culture in the northern part of the DnieperDonets forest-steppe as a result of population movement from areas of the steppe and forest-steppe in the south from the time of "Scythian wars" in the $3^{\text {rd }}$ century ${ }^{115}$.

In the early 90's monuments in the Dnieper-Donets watershed were included in the Seim-Donetsk variant of Kiev culture $^{116}$ and was allocated the line of cultural development of the Roman period - beginning of early Middle Ages, segments of which became Late Zarubinets horizon - Kiev Culture - Pen'kovka/Kolochin Cultures ${ }^{117}$.

Over 1990-2013 came a sufficiently large number of publications, which formulated problems of cultural
109 BARAN 1981, 164-165.
110 SPITSYN 1948, 67.
111 LIAPUSHKIN 1950, 22
112 MAGOMEDOV 2001.
113 BARAN 1981.
114 TERPILOVSKIY/ABASHINA 1992; TERPILOVSKIY 1984.
115 SYMONOVICH 1984.
116 OBLOMSKIY 1991, 62-63, 86-89; TERPILOVSKIY/ABASHINA 1992, $21,152-173$
${ }_{117}$ OBLOMSKIY 1990 
development of the region in the Dnieper-Donets foreststeppe in the Late Roman Period - in the early era of the Great Migration. The first group of issues concerns the time line determined by approximately mid- $3^{\text {rd }}-$ early $4^{\text {th }}$ centuries. Now there are two main concepts of cultural development in the region at this time. First got the most complete expression in the works of A.M. Oblomskiy ${ }^{118}$, some of its constituents are presented in the works of A.N. Nekrasova ${ }^{119}$, R.V. Terpilovskiy ${ }^{120}$, V.D. Baran ${ }^{121}$, B.V. Magomedov ${ }^{122}$. The main points:

1. Cultural groups. Monuments of Seim-Donetsk variant of Kiev Culture are divided into two groups (two stages of development): Bukreevka 2 - Tazovo (mid- $3^{\text {rd }}$ - early $4^{\text {th }}$ centuries) and Kamenevo 2 - Komarovka 2 (4 $4^{\text {th }}$-early $5^{\text {th }}$ centuries). Group Bukreevka 2 - Tazovo is genetically connected with previous Late Zarubinets monuments and Early Kiev monuments of Shyshyno 5 - Shmyriovo type ${ }^{123}$, is synchronous with the first phase of development of Chernyakhiv burial grounds in Ukrainian forest-steppe in the system of E.L.Gorokhovskiy (about AD 230-270) ${ }^{124}$. Compared with the antiquities of Shyshyno 5 - Shmyriovo type, on the monuments Bukreevka 2 - Tazovo type can be seen the emergence of new traits (set of moulded utensils, dwelling construction, household equipment) as a result of influence of Chernyakhov Culture ${ }^{125}$.

Chernyakhiv monuments are also divided into two chronological groups, synchronous to two mentioned groups of Kiev Culture: 1) so-called Chernyakhiv "bases of colonization" and "elements" in the mid-3rd - early 4th centuries; 2) "classical" Chernyakhov Culture of the 4th early 5 th century (or monuments of Snagost 2 - Khokhlovo 2 type $)^{126}$.

2. Emergence of Chernyakhov Culture in the mid-3 $3^{\text {rd }}$ early $4^{\text {th }}$ centuries. A.N. Nekrasova believed that in the second half of the $3^{\text {rd }}$ - at the turn of the $4^{\text {th }}$ century elements and "some traditionds of provincial-Roman Chernyakhov Culture" appeared among carriers of Kiev Culture on the monuments of "types of Rodnoi Krai 3, Boromlia 2 (lower horizon), Bukreevka 2 types” (or group of Bukreevka 2 Tazovo according to terminology of A.M. Oblomskiy). Under the penetration of these elements she implies movement of a group of the Slavic population from the Dniester (monuments of Demianov-Cherepin type), which blends with Kiev tribes (group of Bukreevka2-Tazovo) and brings tradition of Chernyakhov Culture ${ }^{127}$. A.M. Oblomskiy also considers Upper Dniester as the original district of new elements $^{128}$.

B.V. Magomedov assumes that between AD 238-270 the territory of Chernyakhov Culture covers mainly the regions of "Western and Central Ukraine", "Moldova", in

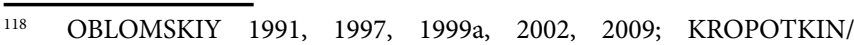
OBLOMS'KIY 1991.

119 NEKRASOVA 1990a; NEKRASOVA 1990b.

120 TERPILOVSKIY 2002, 25; 2004a, 474; 2004b, 42, 44-45, 52-53.

121 BARAN 2004; BARAN, GOPKALO 2005, 45-52.

122 MAGOMEDOV 2001, 139.

123 OBLOMSKIY 1999a, 26; 2002, 56-57.

124 OBLOMSKIY 2002, 60; GOROKHOVSKIY 1988, 42-43.

125 OBLOMSKIY 1997, 64.

126 NEKRASOVA 1990a, 1990b; KROPOTKIN/OBLOMS'KIY 1991.

127 NEKRASOVA 1990a; NEKRASOVA 1990b.

128 KROPOTKIN/OBLOMS'KYI 1991, 88.
}

Kiev monuments (Bukreevka 2 - Tazovo types) Chernyakhiv import and "other signs contacts" appear ${ }^{129}$.

V.D. Baran unequivocally identifies the monuments of Demianov-Cherepin type with Chernyakhov Culture and appearance of their elements in the Dnieper-Donets forest-steppe attributes to the penetration of Chernyakhov Culture at such an early period ${ }^{130}$. R.V. Terpilovskiy opposes the hypotheses about the migration of Upper Dniester population to the east in the middle of the $3^{\text {rd }}$ century and its blending with local Kiev population, but notes that on the west-east line occured constant micromigrations of small population groups both "early Chernyakhiv groups" and part of "Upper Dniester population", related to local Kiev tribes. According to him, the monuments of Cherepin and Boromlia 2 type are related phenomena ${ }^{131}$.

If A.N. Nekrasova, B.V. Magomedov talk about the penetration of Chernyakhov Culture elements and traditions, then A.M. Oblomskiy writes about the emergence of "points with Chernyakhiv cultural context", "monuments of Chernyakhiv type" or Chernyakhiv "bases of colonization" (settlements of Golovino 1, Novosiolovka, Peschanoe, Khokhlovo 2, Khlopkov 1, Radutskovka), penetration of groups of Chernyakhiv population and its steady inclusion in the composition of Kiev communities in the mid- $3^{\text {rd }} c$. without the formation of isolated complexes, but with the steady distribution by majority of objects on a par with Kiev ones ${ }^{132}$. At one of such "bases" - settlement of Golovino 1 in the Upper Reaches of the Severskiy Donets presented mixed in the ethnic composition population, but ethnicity of most groups was Chernyahiv, and this period corresponded to the nearby Chernyakhiv burial ground ${ }^{133}$.

Chernyakhov Culture in the region at an early stage looks quite specific: there are no funeral complexes of this time at Chernyakhiv burial grounds ${ }^{134}$ and early appearance of Chernyakhov Culture on the left bank of the Dnipro is fixed only indirectly - by some chronological indicators (fibulae, amphorae) $)^{135}$.

A.M. Oblomskiy attributes movement of the east carriers of Chernyakhov Culture and Chernyakhiv elements to the earlier time - the mid-second half of the $3^{\text {rd }}$ century and synchronizes this phenomenon with the first (Ruzhychanka phase) phase of development of Chernyakhiv burial grounds in the Ukrainian steppe. He suggests that then there operated pottery centers with furnaces, because it is difficult to imagine a wide export of pottery to the Dnieper-Donets watershed from the Middle Dnieper - Nadporozhie ${ }^{136}$.

3. Kiev-Chernyakhiv contacts. On the materials of the Left Bank of the Dnipro the time of direct contacts is subdivided by R.V. Terpilovskiy into three stages. The first stage (mid- $3^{\text {rd }}$-early $4^{\text {th }}$ centuries) is characterized by the movement of Chernyakhiv population groups of different origin with biritual funeral rite, distinctive pottery, a specific

\footnotetext{
129 MAGOMEDOV 2001, 134-147.

130 BARAN 2004; BARAN, GOPKALO 2005, 45-52.

131 TERPILOVSKIY 2004a, 474; 2002, 25.

132 OBLOMSKIY 1991, 141.

133 OBLOMSKIY 1991, 142, 1997, 69.

134 OBLOMSKIY 1991, 86, 141; OBLOMSKIY 1997, 67-69; OBLOMSKIY 1999a, 26-29; OBLOMSKIY 2002, 56-57, 89

135 TERPILOVSKIY 2004b, 52.

136 OBLOMSKIY 1997, 68-69.
} 
set of items. They move up to the Severskiy Donets in the east, in AD 230-270 appear "seats of Chernyakhiv colonization" (Bol'shaia Danilovka, Golovino 1, Novosiolovka). Simultaneously, carriers of monuments of Bukreevka 2 Tazovo type obtain the same chronological indicators as Chernyakhiv population has (fibulae Almgren VII, horn combs Thomas I, light-coloured clay amphorae of Shelov D type $)^{137}$. There is no sharp breaking of traditions complex, but there appear new features in all areas of archaeological culture. M.B. Shukin considers it is unlikely that the descendants of the inhabitants of short and scattered Late Zarubinets settlements composed general population of Chernyakhov Culture in the region. These descendants entered Kiev Culture structurally rather different from Chernyakhov Culture and in Chernyakhiv settlements inhabited only representatives of Kiev culture ${ }^{138}$.

Another concept of the cultural process is reflected in the works of V.M. Goriunova, G. A. Romanova, O.A. Sheglova $^{139}$, M.B. Shukin ${ }^{140}$, M.V. Liubichev ${ }^{141}$.

1. Cultural groups. Around in the middle (probably the last quarter) of the $3^{\text {rd }}$ - first quarter of the $4^{\text {th }}$ centuries in the region existed so-called monuments of the "horizon of Boromlia". M.B. Shukin understood by it the monuments of the Dnieper left bank containing ceramics of Wielbark or Przeworsk look, as well as ceramics of Demianov-Cherepin type $^{142}$. M.V.Liubichev expanded the scope of the term assuming that the horizon of Boromlia represents a group of settlements emerged as a consequence of migration of the part of carriers of monuments of Demianov-Cherepin type from Upper Dniester, including some elements of Chernyakhov Culture, but weren't Chernyakhov Culture themselves. The horizon of Boromlia represents one of the areas of so-called "Proto-Slavic" culture province of the Late Roman Period along with other areas in the forest-steppe zone of the Upper Dniester to the Upper Don: monuments of Demianov-Cherepin type, Kiev Culture of the Middle Dnieper and Podesenie, monuments of Sedelki-Kashyrka type $^{143}$.

The horizon of Boromlia is not the next step in the evolutionary development of Shyshyno 5 - Shmyriovo group under Chernyakhiv influence (although these groups have some similarities in depressed constructions in the settlements and ceramic complex). The emergence of a complex of innovations in all spheres of material culture from the mid-3rd century is connected not with the "influence of the Chernyakhiv", but with the arrival of a group of population (carriers of monuments of DemianovCherepin type) with already established morphology of material culture in which included Chernyakhiv elements.

The thesis was proposed that there is so-called "fibula chain" between the "Trans-Dniester" and "Dnieper-Donetsk" concentration areals of fibulae with high receiver of group

\footnotetext{
17 TERPILOVSKIY, 2000, 305; TERPILOVSKIY 2002, 21; TERPILOVSKIY 2004a, 471; OBLOMSKIY 1991, 90-114.

138 SHUKIN 2005, 133.

139 GORIUNOVA/ROMANOVA/SCHEGLOVA 1991.

140 SHUKIN 2005, 133.

141 LIUBICHEV 2003; LIUBICHEV 2005b; LIUBICHEV 2008a; LIUBICHEV 2008 b.

142 SHUKIN 2005, 133.

143 LIUBICHEV 2008a; LIUBICHEV 2010, 164-165.
}

VII O. Almgren, which indicates the path of migration of part of the carriers of monuments of Demianov-Cherepin type to their "relatives" in "Proto-Slavonic" cultural province - monuments carriers of post Zarubinets horizon in the Dnieper-Donets forest-steppe ${ }^{144}$.

2. Emergence of Chernyakhov Culture in the mid-3 $3^{\text {rd }}$ early $4^{\text {th }}$ centuries If middle and final phases of Chernyakhov Culture $\left(4^{\text {th }}-\right.$ early $\left.5^{\text {th }}\right)$ are represented by a significant number of settlements and burial grounds, the early phase (second half of the $3^{\text {rd }}$-early $4^{\text {th }}$ centuries) in the region is marked only by certain forms of pottery and certain items specific to Chernyakhov Culture (fibulae of group Almgren VII, horn combs with low semicircular back, amphorae Shelov D) in the monuments of the horizon of Boromlia. There is no known Chernyakhiv burial ground in the Dnieper-Donets forest-steppe for the stages of C1b-C2. Chernyakhiv "bases of colonization" (above all Golovino 1) are nothing more than villages of the Late Roman Period with two horizons: Pre-Chernyakhiv (horizon of Boromlia) and Chernyakhiv. In most cases, on the places of villages of the Pre-Chernyakhiv horizon then appeared settlements of "classical" Chernyakhov Culture, but this overlap is not always fixed stratigraphically. Cases of such overlap are fixed in Boromlia 2, Gochevo 3, Gochevo 4, Voytenki 1 (segment “A») $)^{145}$.

A.I. Zhurko on the example of several studied settlements of the Late Roman Period near the city of Sumy was one of the first who came to the thoughts about the heterogeneity of Chernyakhiv settlements, which is explained by us by the phenomenon of overlap in some cases of villages of the horizon of Boromlia by the villages of "classical" Chernyakhov Culture. He assumes that moulded ceramics in Peschanoe village distinguishes this monument from Chernyakhiv settlements of the microregion (Kosovshina, Krasnopol'e, Velikiy Bobrik) and indicates of the coexistence in the Dnieper-Donets forest-steppe at least two groups of monuments of Chernyakhov Culture: "monuments of one group contain only pottery in the cultural layer and objects, monuments of another group represent both pottery and moulded utensils"146.

3. Kiev-Chernyakhiv contacts. Presence of the horizon of Boromlia with Chernyakhiv elements creates the picture of Kiev-Chernyakhiv contact zone in the middle of the 3rd early 4th century, which disappears from the second quarter of the 4th century, when the region appears so-called "classical" Chernyakhov Culture with different morphological characteristics. There is no symbiosis between carriers of Kiev and Chernyakhov Culture.

The second group of problems is connected with the period from the early-first quarter of the 4th to the first quarter of the mid-V century: residence time of the "classical" Chernyakhov Culture in the region, undermounded burials with Chernyakhiv items, groups of monuments of Kamenevo 2-Komarovka 2 type (Fig. 17). On the final stretch of this period Chernyakhov Culture ceases to exist, new cultural groups appear.

\footnotetext{
144 LIUBICHEV 2003, 77; LIUBICHEV 2008a, 51.

145 LIUBICHEV 2013, 25-26.

146 ZHURKO 1994, 217.
} 
1. Cultural situation in the region in the $4^{\text {th }}$ - early $5^{\text {th }}$ century. According B.V. Magomedov at the stage of "Stabilization of Chernyakhov Culture" (in about AD 270330) Chernyakhiv population occupies a strip along the left bank of the Dnieper, burial grounds of Sosnova, Pereiaslav, Gradizhsk, Kompaniytsy appear. Then, in the "era of Germanaric" (in about AD 330-375) occurs mass distribution of Chernyakhiv monuments in the forest-steppe zone of Eastern Ukraine, which before belonged to the region of the Seim-Donetsk group of Kiev Culture. Repressed population goes to the north and east, increasing population density of Desna Group of Kiev Culture in the forest zone (Fig. 17). According to the researcher, these events are reflected in the story Iordan about the campaign of Germanaric against herules and venetes. At the stage of "Invasion of hunnes and final of Chernyakhov Culture» (from 375) after the collapse of the "power of Germanaric" Vitimir Group is localized in eastern Ukraine. After the death of Vitimir Alateus ans Safrax take away the Goths and the Alans to the Danube. Appear Kantemirovka undermounded burials, then Slavic population returns to the deserted land: on the Psel and the Sula appear postkiev settlements ${ }^{147}$.

2. Correction of boundaries of Chernyakhov Culture areal. V.V. Kropotkin and A.V. Kropotkin considered that on the Left Bank of the Dnieper northern border of the spread of amphorae approximately coincided with the northern boundary of Chernyakhov Culture areal and only in individual cases fragments of light-coloured clay narrownecked amphorae are found at the Kiev-Postzarubinets settlements ${ }^{148}$. A.M. Oblomskiy and A.V. Kropotkin marked north-eastern section of the area of culture (monuments of Snagost' 2 - Khokhlovo 2 type) along the watershed of Tuskar' and Rogozna, the Psel-Seim interfluve, Turovets valley, lower and middle reaches of the Peny, upper reaches of the Vorskla, to the north of Belgorod, at the mouth of the Plot' to the confluence of the Nezhegol' into the Severskiy Donets $^{149}$. O.A. Radiush specified the border of Chernyakhov Culture areal in Kursk Poseymie ${ }^{150}$. M.V. Liubichev and K.V. Myzgin specified southern section of the border of culture areal and now it passes through: the mouth, right bank of the Orel - right bank of the Berestovaya-Gomolsha Rivers ${ }^{151}$.

3. Kiev-Chernyakhiv contacts of the $4^{\text {th }}-$ early $5^{\text {th }}$ centuries. Since the second quarter of the 4th century, according to R.V. Terpilovskiy, begins the second stage of these contacts, characterized by mass Chernyakhiv colonization, exclusion of Kiev tribes from the forest-steppe, which is proved by cases of overlapping of Kiev horizons by Chernyakhiv ones (Gochevo 4, Boromlia 2) ${ }^{152}$. Instead of "marginal zone", typical for the first period of contacts, Kiev monuments of the 4th century are known exclusively outside the territory of Chernyakhov Culture: to the north (right bank of the Seim) and east of its areal ${ }^{153}$. The third stage (second half of the 4 th - early 5 th century) is marked

\footnotetext{
147 MAGOMEDOV 2001, 134-147.

148 KROPOTKIN/KROPOTKIN 1988, 169.

149 KROPOTKIN/OBLOMS'KIY 1991, 77.

150 RADIUSH 2008; RADIUSH 2010; RADIUSH 2011a; RADIUSH 2011 b.

151 LIUBICHEV, MYZGIN, in print.

52 TERPILOVSKIY 1999, 39; TERPILOVSKIY 2000, 305.

3 TERPILOVSKIY 1999, 39; TERPILOVSKIY 2004b, 52-53; OBLOMSKIY 2002,89 .
}

by close contacts in the final phases of development of both cultures, which is identified with the wars of «antes of Bozes» and "goths of Vinitarius» according to Iordan ${ }^{154}$. Since the turn of the 4 th -5 th centuries Kiev population again enters the pool of the Sula and Psel rivers ${ }^{155}$.

4. Cultural (ethnocultural) components of Chernyakhov Culture in the region. In Chernyakhov Culture of the region researchers identify three cultural (sometimes they are called "ethnic") traditions: Wielbark, Scithian-Sarmathian, $\mathrm{Kiev}^{156}$, though a conclusion was drawn about the absence of the territory in Chernyakhov Culture areal of the region, dominated by antiquities of a single ethnocultural tradition and about separate existence of Wielbark and ScythianSarmatian population within the culture ${ }^{157}$.

To the complexes of Scithian-Sarmathian tradition in the region refer burials containing skeletons with bent and crossed lower limbs, deformed skulls, and specific moulded ceramics. It was noted that in the settlements this tradition is less allocated than in the burials: it is possible to attribute rounsided moulded pots with ochreate whisk ${ }^{158}$. Based on the placement of undermounded burials with Chernyakhiv items it was concluded that left bank Sarmathians monuments (unlike the Lower Danube) are located outside Chernyakhov Culture areal, i.e. eastern Sarmatians were not a part of the power of Germanaric ${ }^{159}$.

B.V. Magomedov considers that in Chernyakhov Culture areal are virtually unknown synchronous to it burials of nomadic Sarmathians. Only individual burials of ground burial and Chernyakhiv items in some catacombs of the Lower Don region indicate of relations of Chernyakhiv population and nomadic Sarmatians until AD $375^{160}$. Concerning the Late Scythian element B.V. Magomedov supposes that around the turn of the $3^{\text {rd }}-4^{\text {th }}$ centuries part of the late Scythians moves to the area of Eastern Ukraine. With the Late Scythian element he associates pits with shoulders ${ }^{161}$. But A.M. Oblomskiy believes that we have no opportunity to subdivide Scythian and Sarmatian components in the Sarmatian time, and we can talk only about the Scythian-Sarmatian traditions ${ }^{162}$.

To Kiev tradition refer monuments with the predominance of grey-coloured clay pottery, but with moulded utensils similar Kiev utensils ${ }^{163}$. Kiev tradition is allocated by A.M. Oblomskiy only on the basis of settlements materials (Peshanoe, Velilikiy Bobrik, Mamroi 2, Khlopkov 1). In the settlements of Radutskovka, Maksimovka, Khlopkov 1, Novolipovskoe were defined complexes with "Early Slavic" moulded ceramics ${ }^{164}$. Important role in solving the problem of presence of Kiev element on the monuments of Chernyakhov Culture in the region is played by materials of the settlement of Khlopkov 1, the evaluation of which is highly controversial. O.M. Prikhodniuk believes that the
154 TERPILOVSKIY 2000, 306-307.
155 TERPILOVSKIY 2004b, 53.
156 OBLOMSKIY 2002, 45-50; NEKRASOVA 1990a; NEKRASOVA 1990b.
157 OBLOMSKIY 2002, 47, 50.
158 OBLOMSKIY 2002, 47-49.
159 SIMONENKO 2012, 233.
160 MAGOMEDOV 2001, 122-123.
161 MAGOMEDOV 1996.
162 OBLOMSKIY 2002, 48.
163 OBLOMSKIY 2009, 265.
164 ABASHINA/OBLOMSKIY/TERPILOVSKIY 1999. 
most representative samples of moulded dishes come from the cultural layer. These include: $45 \%$ of biconical pots, $20 \%$ of "grain dish", $8 \%$ of rounded pots. In his opinion, there are two layers in the ancient settlement: Chernyakhiv and Pen'kovka ${ }^{165}$. A.M. Oblomskiy considers that presence of both moulded ceramics of Kiev-Penkovsky look and Chernyakhiv pottery in some conventionally closed complexes (dwelling 4 , pit 8,13$)$, presence of moulded ceramics together with pottery in the filling of dwellings $1,2,3$, pits $14,15,20$, 33 indicates that this moulded ceramics was a part of the whole ceramic complex of Chernyakhiv settlement ${ }^{166}$. Consequently, in this case we can talk about the settlement as a monument of Kiev tradition in Chernyakhov Culture in the region.

At the burial grounds to the manifestation of Kiev tradition refer the presence of biconical urn pot in the cremation burial 1 of Rodnoi Krai 1 and weak-shaped roundsided pot from so-called burial 5 of Uspenka ${ }^{167}$. In Kompaniytsy specific burials with distinctive moulded ceramics and fibulae of circle of "pitted enamel" are associated with Kiev element $(\bigotimes 2,58,60,93)^{168}$.

German (Wielbark-Przeworsk) element in the area of culture links to "long houses" biritualizm of burial grounds, where there are simple pits of northern orientation, Wielbark ceramics, pottery imitation of Wielbark moulded shapes, some items of clothing, jewelry, household items, weapons of Central European types ${ }^{169}$. E.V. Makhno found analogies to cremations with broken crockery in Kompaniytsy in Przeworsk environment ${ }^{170}$.

As reference monument of manifestation of Wielbark tradition in moulded ceramics A.M. Oblomskiy considers the settlement of Belopol'e, after the conclusion of the excavations' author A.N. Nekrasova of German belonging of its inhabitants ${ }^{171}$. He calls the number of settlements (Dubovoe 1, Zvanoe 1, Progress and burial grounds (Rodnoi Krai 1) with single findings of such ceramics ${ }^{172}$. At the settlement of Bukreevka 2, attributed by A.M. Oblomskiy to Seim-Donetsk variant of Kiev Culture, by unit finds of Wielbark ceramics he traces the signs of influence of Wielbark traditions on Kiev ceramic complex ${ }^{173}$. By ceramics finds of this tradition in the objects of the second phase of Boromlia settlement he concludes about syncretism of their pottery ${ }^{174}$. Analyzing Wielbark features on Chernyakhiv burial grounds in the region and in Chernyakhov Culture areal in general, scientist comes to the conclusion that burials of this traditions are committed in simple pits without lining with the position of the skeletons on the back ${ }^{175}$. Kompaniytsy burial ground with German component is associated with cremation and inhumation containing specific moulded ceramics, as well as some types of cremation covering urns or a handful of bones with fragments of pottery, in which

165 PRIHODNUK 1998, 73

166 OBLOMSKIY 2002, 41.

167 OBLOMSKIY 2002, 49.

168 OBLOMSKIY 1999b, 82

169 MAGOMEDOV 1998; MAGOMEDOV 2001, 23-24, 41-43, 115-120.

170 MAKHNO 1971b, 89-90.

171 NEKRASOVA 1994

172 OBLOMSKIY 2002, 45

173 OBLOMSKIY 2002, 45.

174 OBLOMSKIY 2002, 46

175 OBLOMSKIY 2002, 47.
Wielbark ceramics or only pottery is presented ${ }^{176}$.

The viewpoint of I.V. Zin'kovskaya stands somewhat apart. Recognizing the multiethnic character of carriers of culture in the region, she concludes about the changing of ethnicity of the population over the lifetime of Chernyakhov Culture and the presence of two cultural and chronological traditions on the funeral monuments: in the last third of the $3^{\text {rd }}-4^{\text {th }}$ centuries there are extensive Kompaniytsy, Uspenka, Pereyaslav-Khmel'nitskyi necropolises, left by multiethnic conglomerate (Goths-Gepids, Sarmanians, Slavs), then in the middle of the 4th century appear small biritual burial grounds of Goths-Gepids ${ }^{177}$.

This viewpoint finds no support in archaeological sources. Different cultural traditions are demonstrated not only by mentioned burial grounds, but also by the other, which burials can be dated back to the mid-second half of the $4^{\text {th }}$ century: Voytenki, Boromlia, Rodnoi Krai 1, Sumy-Sad, Kantemirovka ${ }^{178}$. Concerning the size "reduction" of burial grounds one can notice that in Kompaniytsy, Uspenka, Pereyaslav-Khmel'nitskyi were investigated respectively 111 , 34, 42 burials $^{179}$. By 2013 in Voytenki 190 burials had been studied ${ }^{180} .48$ burials were opened on the partially destroyed burial ground of Boromlia $1^{181}$.

5. Role of materials of Boromlia 2 settlement in the construction of the cultural development concept. Initially, even during the excavations of the monument, the thesis was proposed about the presence of "two chronological horizons" and absence of chronological gap between them ${ }^{182}$. According to the authors of excavations - A.N. Nekrasova and R.V. Terpilovskiy, abrupt change of ceramic complex suggests the emergence in the early 4 th century of the new population, which makes extensive use of pottery ${ }^{183}$.

Then, was drawn the conclusion about three horizons in the ancient settlement: 1 - with objects (constructions 1 , 6,10 , dwelling 3 , hearth 2 ) filled with $70-90 \%$ of moulded ceramics and also pottery, mainly polished ceramics; 2 - with objects (dwellings 7,8 , construction 5 , presumably "aboveground construction" with hearth number 1 , probably hearths 3,4 ), containing $34-60 \%$ of moulded ceramics, including the north-western tradition; 3 - objects (household buildings 2, 4 , 9, furnaces 1 , 2, pits $1-10$, “working platform"), containing $90-100 \%$ of pottery. It is believed that the objects of the first horizon fix the appearance of new ethnocultural elements through the emergence of Chernyakhiv pottery among local tribes of Kiev culture in the second half of the 3rd - the turn of the 3rd-4th centuries. Objects of the second horizon reflect population coming from the west in the first half of the 4th century, objects of the third horizon already represent fully developed Chernyakhov Culture of the second half of the 4th century $^{184}$.

6. Place of Kamenevo 2 - Komarovka 2 group in the cultural process. Apart from Chernyakhov Culture during

\footnotetext{
176 OBLOMSKIY 1999b, 79.

177 ZIN'KOVSKAYA 1997, 14, 18.

178 LIUBICHEV 2013, 21-22.

179 NEKRASOVA 2006; GONCHAROV/MAKHNO 1957.

180 LIUBICHEV/MYZGIN/VARACHEVA/SCHULTZE 2014.

181 NEKRASOVA 2006.

182 NEKRASOVA/TERPILOVSKIY 1990, 19, 26.

183 NEKRASOVA/TERPILOVSKIY 1990, 26-27

184 NEKRASOVA/TERPILOVSKIY 1990, 19-20; NEKRASOVA 2006, 94-95.
} 
this period in the area of the Dnieper-Donets forest-steppe existed and other associations. As foreign phenomenon in the area of Chernyakhiv settlements and burial grounds, as well as monuments of the Seim-Donetsk variant of Kiev culture A.M. Oblomskiy considers six ancient settlements: Kamenevo 2, Peschanoe Komarovka, Besedovka (Late Kiev period of the settlement), Kurgan-Azak, Sencha ${ }^{185}$. Ceramic complex structure distinguishes these monuments from the settlements of "Kiev tradition in Chernyakhov Culture» (Golovino - Mamroi - Khlopkov) and from KievDonetsk ancient settlements of the Seim-Donetsk variant of Bukreevka - Tazovo type ${ }^{186}$. Researcher finds their proximity to the monuments of Kiev Culture of Podesenya «Ulianovka circle» and concludes about the appearance of the Desna population in the forest-steppe under the impact of Chernyakhov Culture. The conclusion was drawn about the presence of "Ulianovka circle» monuments in the forest-steppe zone and in the areal of Chernyakhov Culture (Kurgan-Azak, Sencha, Besedovka) and in the areal of the Seim-Donetsk variant of Kiev Culture (Komarovka, Kamenevo, Peschanoe), that indicates of the penetration of "Desna protokolochinskiy population" to the eastern part of the region - to the upper reaches of the Seim and Psel rivers $^{187}$.

7. Determination of chronology of Chernyakhov Culture in the region. Burial ground materials of the region served as sources for the development of chronological systems of Chernyakhov Culture in the Ukrainian forest-steppe, in its areal on the territory of modern Ukraine and Moldova in general and the Middle Dnieper in particular. By the method of chronological horizons isolation of similar complexes on the materials of a large part of the culture areal the scheme E.L. Gorokhovskiy was created ${ }^{188}$. The scientist haveidentified five phases of burial grounds development in the area of forest-steppe on both sides of the Dnieper, synchronized with all-European phases in the K. Godlowski - J. Tejral system: 1) Ruzhchanka (stage C1b, early segment C2, about 230-270); 2) Berezhanka (late segment C2, about 270-330) 3) Kosanov (stage C3, about 330-380); 4) Maslov (late segment C3 - early D1; around 350 - 400) 5) Zhuravka (stage D1; about 375/380-420/430) phases. To the phases 2 - 5 linked complexes from burial grounds of Sosnova, Kompaniytsy, Sumy-Sad, Uspenka, Pereyaslav-Khmel'nitskiy, Zhovnin, Lokhvitsa, Rodnoi Krai 1, Kantemirovka (undermounded burials), and separate burial at Grechaniki ${ }^{189}$.

Composing the chronology of Chernyakhiv burial grounds by O.A. Gei and I.A. Bazhan by applying the correlation method has become an integral part of attempts to create a chronological scale for Eastern Europe and the Black Sea coast of the Caucasus of the I-VI centuries. For this were used materials, including Kompaniytsy burial ground, enclosed into so-called "Middle Dnieper block" of burial grounds ${ }^{190}$. Such development periods of Chernyakhov Culture were defined: 1) about 230/240-270/280 (including Kompaniytsy, burial 171); 2) about 270/280-310/320

\footnotetext{
185 OBLOMSKIY 2002, 69.

186 OBLOMSKIY 2002, 70.

187 OBLOMSKIY 2002, 72.

188 GOROKHOVSKIY 1988.

189 GOROKHOVSKIY 1988, 45-46.

190 GEI/BAZHAN 1997, 41, tabl. 63-65.
}

(including Kompaniytsy, burial 1, 8, 130); 3) about 310/320$350 / 355$; 4) about 350/355-375; 5) about 375-400/410

The chronology scheme of Cherniakhov monuments of the Middle Dnieper by O.V. Petrauskas - R.G. Shishkin is "tied" to the European chronological system. It contains phases C1b (first half of the $3^{\text {rd }}$ century), C2 (second half of the $3^{\text {rd }}$ century), C3 (first half of the $4^{\text {th }}$ century) (burials 2, 5 of Pereyaslav-Khmel'nitskiy), D1 (end of the $4^{\text {th }}-$ early $5^{\text {th }}$ century) (burials 1 of Zhovnin/Bilenkovy Burty, 71 and 118 of Kompaniytsy, 26 of Zhovnin/Pristan'), D1-D2 (first half of the $5^{\text {th }}$ century) (Khlopkov settlement, materials from Gradizhsk, burials 388 of Sosnova, 69 of Kompaniytsy ${ }^{192}$.

8. Final of Chernyakhov Culture and cultural development of the region in the early era of the Great Migration. A.M. Oblomskiy first identified the Hun Period for the Dnieper-Donets forest-steppe, which he associates with the emergence of the Huns, the defeat of the power of Germanaric, massive population movement, destruction of archaeological communities system of the Late Romen Period $^{193}$.

A.M. Oblomskiy marks historical processes of the Hun times in the form of several vectors: 1) outflow of Chernyakhov Culture population, movement of its groups to the west, as well as migration to the Upper Don region; 2) movement of population groups from the Middle Dnieper to Podesenie; 3) movement of population from Podesenie and adjacent Poseymie to the east and south; 4) movement of the carriers of the Seim-Donetsk variant of Kiev Culture to the Don region; 5) appearance of monuments of "steppe circle" traditions in the southern part of Chernyakhov Culture areal or near its borders ${ }^{194}$.

According M.B. Shukin, for a given period we don't known archaeological cultures in the usual content of this term. The main body of the finds is grouped into a number of different short-term cultural groups on a restricted area "horizons of one style finds"195. Elements of a new subculture originate within the preceding stage ${ }^{196}$. The concepts of «Late Chernyakhov Culture» and «Late Chernyakhiv population» are introduced ${ }^{197}$.

Most experts believe that at the beginning of the Hun era on the large part of the region Chernyakhiv population continued to exist ${ }^{198}$. Chernyakhiv groupings in great numbers leave the region a little later, and in this period the distribution of some elements of material culture (fibulae and certain types of glass vessels) gives the impression of some of its isolation from the other parts of Chernyakhov Culture areal ${ }^{199}$. According E.L. Gorokhovskiy, Kantemirovka mounds are the evidence of preservation of Chernyakhov Culture material complex in the first third of the V century ${ }^{200}$. M.B. Shukin believed that after the hunnes invasion receded Chernyakhiv population stayed on the former territory and
91 GEI/BAZHAN 1997, 41-49, tabl. 66-70.
192 PETRAUSKAS/SHISHKIN 2010.
193 OBLOMSKIY 2002, 61.
194 OBLOMSKIY 2002, 98-99.
195 SHUKIN 1979, 18.
196 SHUKIN/SHAROV 2000, 376.
197 KAZANSKIY/MASTYKOVA 2009, 226, 234.
198 TRETIAKOV 1970, 50; KAZANSKIY 1997, 183; OBLOMSKIY 2002, 90;
GAVRITUKHIN 2007, 24.
199 GAVRITUKHIN 2007, 24.
200 GOROKHOVSKIY 1988. 
continued to use their settlements and cemeteries, to keep old traditions. Therefore goths of Germanaric are difficult to distinguish from goths of Vinitarius ${ }^{201}$.

M.M. Kazanskiy admits the possibility of the arrival of new groups of barbaric population at Chernyahiv areal under the control of the Huns, from the territory of present-day Poland, in favor of which indicates not only Late Przeworsk ceramics of Dobrodzen type in the upper layers of Bashmachka in Nadporozh冈e and Kompaniytsy burial 86, referring to the stage $\mathrm{D} 1^{202}$.

9. Issue about cultural and ethnic attribution of undermounded burials with Chernyakhiv items. Among researchers firmly established opinion about their Sarmatian, Sarmatian-Alan belonging ${ }^{203}$. Later dates of the left bank undermounded burials are evidence that the composition of this culture in the mid-second half of the 4th century included some nomadic groups ${ }^{204}$. The nearest analogies of the mounds of Kantemirovka type A.V. Simonenko finds in the antiquities in the Lower Don region. According to him, they originate from the North Caucasus and have alanes roots $^{205}$.

Chernyakhov Culture split Sarmatian world into two parts. In the Pre-Azov-Don steppe separate burials of the final phase of Late Sarmatian culture tend to the circle of the Lower Don, they border on Chernyakhov Culture areal, sometimes getting into it. Sarmathians (alanes-tanaites) weren't a part of the Gothic association ${ }^{206}$. It seems that Alan-Sarmatians settled on the Dnieper only in the final phase of Chernyakhov Culture, after the defeat in 375 AD by the Huns and Alans of Ostrogothic Union of Germanaric ${ }^{207}$. Late Sarmatian monuments in the eastern Ukraine clearly indicate of territorial (and political?) independence of their carriers with respect to the Gothic association ${ }^{208}$. AlanoSarmatian monuments (Kantemirovka, Novo-Podkriazh, Dmukhailovka), as well as monuments with the North Caucasian ceramics (Kapulovka) wedged between this group and the Goths Gesimundes (Chernyakhiv monuments in the Black Sea steppe: Ranzhevoe, Kamenka-Anchekrak, Gavrilovka, Bisiukov monastery, Lugovoe). They divide Gothic population of the Hun Empire ${ }^{209}$.

10. Attempts to identify historical events from the written sources with archaeological realities. Some dualism is observed identifying archaeological phenomena of the final of the Late Roman Period - beginning of the Great Migration era with historical events, drawn from the written sources. On the one hand, researchers believe that it would be imprudent to look for in the gothic folklore (gothic songs recorded by Iordan) description of real events, to try to locate them in time and space, or believe in the actual existence of absolutely all the characters mentioned there ${ }^{210}$. And on the other hand, archaeological phenomena are almost unequivocally

201 SHUKIN/SHAROV 2000, 375.

202 KAZANSKIY 1997 182; KAZANSKIY/MASTYKOVA 2009, 230.

203 LYAPUSHKIN 1961, 155; KAZANSKIY/MASTYKOVA 1999, 119; SIMONENKO 2012, 230.

204 OBLOMSKIY 2002, 83

205 SIMONENKO 2001, 50

206 SIMONENKO 2001, 90.

207 KAZANSKIY/MASTYKOVA 1999, 125

208 SIMONENKO 2012, 233.

209 KAZANSKIY/MASTYKOVA 1999, 128.

210 KAZANSKIY/MASTYKOVA 2009, 227. identified with historical events and even accurately localize political associations of that time ${ }^{211}$.

M.M. Kazanskiy and A.V. Mastykova assume that by the ethnonym of "alanes-sarmates» Marcian (or PseudoMarcian) one should understand all Iranian-speaking and non-Iranian-speaking tribes of the steppe and adjacent regions, descendants of the ancient Sarmatians and Alans ${ }^{212}$. A.V. Simonenko admits that Ammianus Marcellinus meant by Alanes-Tanaites generally Late Sarmatian tribes of the Northern Black Sea, and by greitunges - population of Chernyakhov Culture ${ }^{213}$.

M.M. Kazanskiy and A.V. Mastykova connect Late Chernyahiv monuments of periods D1 (AD 360/370$400 / 410$ ) - the beginning of D2 (AD 380/400-440/450) (forest-steppe burial grounds including our region: SumySad, Kompaniytsy), "prince» hoards with the East Germanic jewelry of the Untersibenbrunn D2 horizon (Nezhyn, Kruglitsa (Porshyno), Zhygailovo, Bol'shoy Kamnents, Oboyan' district) with the Ostrogoths of Vinitarius, Gunimand-Thorismund ${ }^{214}$. Iordan narrative about coming of the hunnes, Germanaric death and reign of his heirs are treated as the emergence of a few ostrogothes-greitunges enough independent power centers ${ }^{215}$.

It is believed that at the times of the Vinitarius (the 70 's -80 's of the $4^{\text {th }}$ century) Ostrogothes neighbors to the south and south-east were hunnes of Balamber, and in the north - the Antes of king of Boz. These «Antes» are the heirs of Veneti, carriers of Kiev Culture ${ }^{216}$. As the center of the Vinitarius kingdom and its heirs was determined the Dnieper left bank, the northern part of Chernyakhov Culture areal, between the upper reaches of the Voprskla and Psel rivers, where the hoards near Zhygailovka, Nezhyn, Rebliovka, "princely" graves near Bol'shoi Kamenets in 1918-1919 and 1927 were found ${ }^{217}$.

\section{Cultural situation in the region in the light of finds of ancient coins}

After fragments of amphorae, Roman coins are one of the most common categories of finds of ancient import on Chernyakhov Culture monuments of the Dnieper left bank forest-steppe. Condition of source base gives doesn't allow to judge of a more or less exact number of the finds (both published and unpublished). Currently we have information on at least 208 finds points of Roman coins: single finds (including finds from the territories of monuments, in complexes or without context, as well as coins with holes) and hoards. Their total number is not less than 8150 copies (no less than 390 individual finds and not less than 7760 coins in hoards). A total mass of finds from the territory of Chernyakhov Culture it is about $30 \%$ or about $17 \%$ of the finds points on the territory of the culture ${ }^{218}$. Not all findings have complete information about the context and the circumstances of their discovery, and general description

\footnotetext{
211 KAZANSKIY 1997; KAZANSKYI/MASTYKOVA 2009.

212 KAZANSKIY/MASTYKOVA 1999, 119.

213 SIMONENKO 2012, 233.

214 KAZANSKIY 1997, 182; KAZANSKIY/MASTYKOVA 1999, 127, ris. 1

215 KAZANSKYI/MASTYKOVA 2009, 245.

216 KAZANSKIY 1997, 181.

217 KAZANSKYI 1997, 183; KAZANSKYI/MASTYKOVA 2009, 246.

218 MYZGIN 2013a, 356.
} 
of some cast doubt on the authenticity. Therefore, one of the actual tasks of further research of Roman coins in the region is the verification of the available data, based primarily on archival work.

Finds of Republican denarii in the region is rather an exception than the regularity. There is information only about two such coins, but the reliability of information needs to be tested. Prevailing category Roman coins finds is Roman denarii of the I-II centuries, issued mainly between the reigns of Traian and Septimius Severus (98-211 years.). Besides, they predominate both among individual finds (77.9\%) and among the hoards of coins $(92.6 \%)^{219}$. In recent years, the problem of their penetration to the territory of Chernyakhov Culture, including the territory of the region, has gained significant currency. Until the mid-1980s researchers considered the appearance of these coins as a result of trade between the barbarians and the Roman Empire ${ }^{220}$. Since the mid-1980s - until early 2010s among the scientists the most prevalent was the idea of their penetration to the barbaric environment as a result of plunder of Roman provincial towns during the Gothic war221. However, lately the penetration of Roman denarii in Eastern Europe has been associated with the migration of Gothic people from Central Europe in early $3 r d$ century $^{222}$. The last thesis is well illustrated by the results of the analysis of denarii hoards. All seven authentic denarii hoards (Sevenki, Priamicyno, Chutove, Kriachkovka, Lukishina, Rogintsy, Starye Valki/2013), though different in composition, but have a similar chronological structure with different groups of hoards from Central Europe, from the territory of Przeworsk and Wielbark cultures ${ }^{223}$.

Subaeratae denarii compose the second largest group of finds of coins of Early Roman Period. They attracted the researchers' attention not so long ago, but now it has been noticed that mostly these coins had a hole, that is they were altered into pendants ${ }^{224}$. Other denominations of early coinage (sestercii, dupondii etc.) are represented by single finds relating to the category of low reliability.

Antoniniani finds in the region are also rare $(0.8 \%)$, in contrast to the bronze coins of provincial coinage of the $3^{\text {rd }}$ century ${ }^{225}$. Special study of finds of these coins in Chernyakhov Culture areal, held by G. Beidin, showed that on the Left Bank of the Dnieper the finds of coins of provincially-Roman coinage from the cities of Asia Minor (Trapezos, Sinope, Cessarea Cappadocia) compose prevailing number of them (85\%), while on the Right Bank of the Dnieper and in Moldova the number is only $30 \%$ (there are predominant finds of coins of Balkan provincial-Roman cities). Perhaps such correlation illustrates the area of settlement of sea voyages participants to Asia Minor in the middle of the $3^{\text {rd }}$ century ${ }^{226}$. Another feature of the coins in the region of this time is almost complete absence of aurei of 219 MYZGIN 2013a, 356-357.

220 FENIN 1951, 101; BRAICHEVS'KIY 1959, 18; KROPOTKIN 1961, 18 ; RIKMAN 1975, 232; NUDEL'MAN 1982, 129.

221 MAGOMEDOV 1987, 79; SHUKIN 2005, 202; SHAROV 2007, 34 - 35; MYZGIN 2008, p. 51-52.

222 MYZGIN 2013b, 222-223; DYMOWSKI/MYZGIN, in print; MYZGIN/ DYMOWSKI, in print.

223 MYZGIN/DYMOWSKI, in print.

224 MYZGIN 2013a, 362.

225 MYZGIN 2013a, 359.

226 BEIDIN 2012. the $3^{\text {rd }}$ century, typical for the regions of the Middle Dnieper and Dniester ${ }^{227}$.

Coins of the $4^{\text {th }}-$ early $5^{\text {th }}$ centuries aren't typical for the Dnieper left bank. It is all about nine reliable finds of bronze coins $(2.4 \%)$ and one siliqua $(0.25 \%)^{228}$. Quite apart is a hoard, discovered in 1891 near Rubliovka village (Poltava oblast). The hoard consisted of 201 solidi of the end of the $4^{\text {th }}-$ early $5^{\text {th }}$ centuries ${ }^{229}$. Besides, single finds of solidi are known in the region $(0.8 \%)$. This phenomenon a number of researchers associate with the existence of the Postchernyakhiv horizon on the Left Bank of the Dnieper forest-steppe in the first half of the $5^{\text {th }}$ century ${ }^{230}$.

One cannot but touch a very interesting group of finds in the region - the barbaric coins imitations. Until recently, their finds were considered a rarity on the Left Bank of the Dnieper $^{231}$. However, lately, information about their new finds has started intensely accumulating ${ }^{232}$. According to recent data, one can talk about 41 finds of denarii imitations (6.3\% of the total amount) and 12 gold coins imitations (6.3\% of total amount) (barbarous-imitations.narod2.ru). Subject of barbaric imitations on the territory of Barbaricum is today one of the most promising for development ${ }^{233}$.

Another feature of numismatic finds of the Late Roman Period in the region is wide spreading of Bosporan coins. This issue has been actively studied only recently ${ }^{234}$. Most Bosporan coins, found on the left bank of the Dnieper, were minted in the $\mathrm{mid} / \mathrm{second}$ half of the $3^{\text {rd }}-$ early $4^{\text {th }}$ centuries. Apparently, if the coins of mid/second half of the 3rd century (Pharsanzes, Ininthimaeus and Rhescuporis V) came to the region as a result of the German presence in the Bosporus, then the coin of the end of the $3^{\text {rd }}$ - early $4^{\text {th }}$ centuries (Thothorses, Teiranes and Rhescuporis VI) were already the result of some economic ties ${ }^{235}$. However, the question of the causes of the influx of Bosporan coins in the region should be considered open.

Thus, the spread of ancient coins on the territory of the Dnieper Left Bank has a number of features that distinguish this region from others. Namely: significant distribution of coins of the $3^{\text {rd }}$ century of autonomous minting cities of Asia Minor cities; absence of gold coins finds minted in the $3^{\text {rd }}$ century; a small amount of coins minted in the $4^{\text {th }}$ - first half of the $5^{\text {th }}$ century; availability of solidi of the end of the $4^{\text {th }}-$ early $5^{\text {th }}$ centuries; widespread of Bosporan coins. At the same time, in the region, in general, common throughout the whole territory of Chernyakhov Culture elements of spreading of Roman coins are preserved, that is a predominance of denarii of the $1^{\text {st }}-2^{\text {nd }}$ centuries coinage both among single finds and among coins of hoards. Such features of coins distributing can be attributed to several factors. First, the region is most distant from the centers of culture formation and Roman Limes. The latter, in particular, since the $4^{\text {th }}$ century has been the source of a constant influx of coins in the territory to

\footnotetext{
22 BURSCHE 2013.

228 MYZGIN 2013a, 359, 361.

229 KROPOTKIN 1961, 72, No 813.

230 KAZANSKIY 1997; GAVRITUKHIN 2005.

231 MYZGIN 2009, 96, fig. 1, Catalogue.

232 ANOKHIN 2012, 146; barbarous-imitations.narod2.ru.

33 BURSCHE/MYZGIN 2012.

234 BEIDIN/MYZGIN 2010; MYZGIN/BEIDIN 2012.

235 MYZGIN/BEIDIN 2012, 61-63.
} 
the west of the Dniester. In contrast, geographical proximity of the area under consideration to the Bospores enabled influx of import from its territory. Second, distribution of coins in the region was closely associated with the spread of Chernyakhov Culture itself, which took place, according to archaeological evidence, rather late - from the second third of the $4^{\text {th }}$ century. Finally, the third, no less important reason was geographical position of the region, namely the presence of powerful obstacle such as the Dnieper that prevented the rapid spread of new elements here.

\section{REFERENCES:}

\section{ABASHINA/OBLOMSKIY/TERPILOVSKIY 1999}

Abashina N.S./Oblomskiy A.M./Terpilovskiy R.V., K voprosu o ranneslavianskich elementach na cherniachovskich pamiatnikach Srednego Podneprovia', Rossiiskija archeologia 4, 78-98.

ANOKHIN 2012

Anokhin, O.V.,Varvarskie podrazhaniya rimskim monetam na territorii Ukrainy i Moldovy, Prichernomore. Istoria, politika, kultura, VIII ( ${ }^{\text {rd }}$ ) (Sevastopol), 141-151.

ANTONOVICH-MELNIK 1926

Antonovich-Melnik, E., Archeologichni doslidy na Kremenchuzchiny, Korotki zvidomlenna VUAK za 1925 r., 81-86.

BARAN 1981

Baran, V.D., Cherniachivska kultura (Kyiv: vydavnyctvo Naukova Dumka)

BARAN 2004

Baran, V.D., Chernjachivska kultura - polietnichne utvorennia na terytorii Pivdenno-Schidnoi Evropy, Archeologia davnich slovjan (Kiev), 91-102.

BARAN/GOPKALO 2005

Baran, V.D./Gopkalo, O.V., Chernyachivski poselennia baseinu Gnyloi Lipy (Kyiv: vydavnyctvo Naukova Dumka)

BASHKATOV 2010

Bashkatov, Yu.Yu., Pamjatniki chernjachovskoi kultury iuga Srednego Podneprovia. In Scheglova, O./Kazanski, M./ Novakovski, W. (eds.), Germania-Sarmatia II (KaliningradKursk), 215-239.

BASHKATOV/DEGTAR/LIUBICHEV 1997

Bashkatov, Yu.Yu., Degtar, A.K., Liubichev, M.V., Selische pozdnerimskogo vremeni Rodnoi Krai 3 v basseine Severskogo Donza, Drevnosti 1996, 111-121.

BEIDIN 2012

Beidin, G.V., Rimskie provincialnye monety na territorii Ukrainy v areale cherniakhovskoi kultury, Drevnosti 11, 147-159.

BEIDIN/MYZGIN 2010

Beidin, G.V./Myzgin, K.V., Nakhodki bosporskikh monet v areale cherniakhovskoi kultury. In: Scheglova, O./Kazanski, M./Novakovski, W. (eds.), Germania-Sarmatia II (KaliningradKursk), 135-146.

BEREZOVETS/PETROV 1960

Berezovets, D.T., Petrov, V.P., Lochvickyi mogilnik, Materialy $i$ issledovania po archeologii USSR, 82, 84-99.

BERESTNEV/BUINOV/DIACHENKO/SHRAMKO 1979

Berestnev, S.I./Buinov, Yu./Diachenko, V./Shramko, B.A., Raboty novostroechnoi ekspeditsii Kharkovskogo universiteta, Archeologicheskie otkrytia 1978 goda, 302-303.

BOGUSEVICH 1960

Bogusevich, V.A., Pogrebenie cherniakhovskoi kultury v g. Sumy, Kratkie soobschenia Instituta archeologii USSR 10, 103-105 BORODULIN 1975

Borodulin, V.G., Issledovania v zone sooruzhenia Krasnopavlovskogo vodohranilischa, Archeologicheskie otkrytia
1974 goda, 161-162.

BRAICHEVSKIY 1957

Braichevkiy, M. Yu., ,Pro etnichnu nalegnist Chernyakhivskoi kultury, Archeologia 10, 11-24.

BRAICHEVSKIY 1959

Braichevkiy, M. Yu., Rymska moneta na terytorii Ukrainy (Kyiv: vydavnyctvo AN USSR).

BRAICHEVSKIY 1964

Braichevkiy, M. Yu., Bilia dzerel slovianskoi narodnosti (Kyiv: Naukova Dumka)

BURSCHE/MYZGIN 2012

Bursche, A., Myzgin, K., Imagines Maiestatis: Barbarian imitations of Roman coinage. In I. Khrapunov (ed.) Inter Ambo Maria. Northern Barbarians from Scandinavia towards the Black Sea (Simferopol: Dolya), 58-59.

DANILENKO/STOLAR 1952

Danilenko, V.M./Stolar, A.D., Pereiaslavska marshrutna expeditsiya, Archeologichni pamatki URSR 3, 223-230.

DIACHENKO 1976

Diachenko, A.G., Issledovania na Kharkovschine, Archeologicheskie otkrytia 1975 goda, 322-323.

DIACHENKO 1980

Diachenko, A.G., Pamiatki Chernyakhivskoi kultury v baseini Siverskogo Dinzia, Archeologia, 35, 66-73.

FEDOROVSKYI 1927

Fedorovskyi, O., Instrukzii ta programy dla rozvidok i reestrazii pamyatok archeologichnyh (Kharkiv).

FENIN, 1951

Fenin, O.V., Znakhidky rymskykh monet u Prykarpatti, Archeologia V, 92-104.

DYMOWSKI/MYZGIN, in print

Dymowski, A., Myzgin, K., Inflow and redistribution of Roman imperial denarii in the area of Przeworsk, Wielbark and Chernyakhiv cultures and in the Baltic Islands in the lizht of chronological of coin hoards, Notae Numismaticae IX, in print.

GAVRITUKHIN 2005

Gavritukhin, I.O., Nekotorye perspektivy izucheniya finala cherniakhovskoi kultury, Trudy Gosudarstvennogo istoricheskogo muzeia 145, 23-36.

GAVRITUKHIN 2007

Gavritukhin, I.O., Dneprovskoe lesostepnoe Levoberege.Final chernyakhovskoy kultury, Ranneslavyanskiy mir. Archeologia slavyan i ikh sosedey, 9, 9-24.

GEI 1980

Gei, O.A., Seredniodniprovska i pivnichnoprichopnomorska zony cherniakhovskoi kultury (za materialamy pochovalnogo obriadu), Archeologia, 34, 35-53.

GEI/BAZHAN 1997

Gei, O.A., Bazhan, I.A., Chronologia epokhi "gotskikh pokhodov" (na territoriiVostochnoi Evropy i Kavkaza), (Moskva: ONTI PNC RAN).

GEIKO 1999

Geiko, A.V., Cherniakhovske gorno pid Poltavoyu, Arheologichniy litopis Livobereznoi Ukrainy, 1, 76-82.

GEIKO/REIDA/MILASCHEVSKIY 2011

Geiko, A.V., Reida, R.M., Milaschevskiy, O.S., Cherniahivske pohovanna z Lohvichinni (za materialamy doslidzen M.D. Renskogo 1927 r.), Starozitnosty Livoberezhnogo Podniprovia, (Kiev-Poltava), 95-100.

GONCHAROV/MAKHNO 1957

Goncharov, V.K., Makhno, E.V., Mogilnik cherniakhovskogo typu bila Pereiaslava-Khmelnizkogo, Archeologia 11, 127-144.

GORODZOV 1905

Gorodzov, V.A., Rezultaty archeologicheskih issledovanyi v Izumskom uezde Kharkovskoi gub. v 1901 g., Trudy 12 arheologizeskogo siezda 1, (Moskva), 174-225. 


\section{GOROKHOVSKIY 1988}

Gorokhovskiy, E.L., Khronologia cherniakhovskich mogilnikov Lesostepnoi Ukrainy, Trudy V Mezhdunarodnogo kongressa arheologov-slavistov 4, (Kiev), 34-46.

GORYUNOV 1981

Goryunov, E.A., Slavianskoie poselenie serediny I tys.n.e. u s.Peschanoe Belgorodskoi oblasti, Kratkie soobschenia Instituta archeologii AN USSR 171, 61-65.

GORYNOVA/ROMANOVA/SCHEGLOVA 1991

Gorynova, V.M., Romanova, G.A., Scheglova, O.A., K probleme sootnoschenia kievskoi i cherniakhovskoi kultur na teritorii Dneprovskogo Levoberezhia, Drevnie kultury I archeologicheskie izyskania, (Sankt-Peterburg), 75-78.

KAZANSKIY 1997

Kazanskiy, M.M., Ostrogotskie korolevstva v gunnskuyu epokhu: rasskaz Iordana I arkheologicheskie dannye, Stratum plus Peterburgskiy arkheologicheskiy vestnik 3, 23-38.

KAZANSKIY/MASTYKOVA 1999

Kazanskiy, M.M., Mastykova, A.V., Alany na Dnepre v epohu Velikogo pereselenia narodov: svidetelstvo Markiana i archeologicheskie dannye, Rossiyskaya archeologia 4, 119-129.

KAZANSKIY/MASTYKOVA 2009

Kazanskiy, M.M., Mastykova, A.V., Kochevye i osedlye varvary v Vostochnoy Evrope v gunnskuyu epokhu, Divnogorskyi sbornik, (Voronezh) 1, 225-251.

KOVALENKO/LUGOVIY 2008

Kovalenko, O.V., Lugoviy, R.S., Pizniosarmatski pohovanna Storozhivskogo kurgannogo mogilnika, Arheologichniy litopis Livobereznoi Ukrainy, 1.2, 34-44.

KOVALENKO/LUGOVIY 2009

Kovalenko, O.V., Lugovyi, R.S., Storozhivskiu kurgannyu mogilnik. In K. Myzgin (ed.), Ostrogothica (Kharkov), 174-179.

KRAKALO 2004

Krakalo, I., Provinziyno-rymska traditia i posud z Zhovnino v zibranni Kremenchutskogo kraeznavchogo museu, Ukrainskyu keramologichniu zhurnal 1 (11), 139-144.

KROPOTKIN 1969

Kropotkin, V.V., Izuchenie cherniakhovskoi kultury na Poltavschine, Archeologicheskie otkrytia 1968 goda, 310-311.

KROPOTKIN 1961

Kropotkin, V.V., Klady rimskikh monet na territorii SSSR, Svod arkheologicheskikh istochnikov G4-4.

KROPOTKIN/KROPOTKIN 1988

Kropotkin, A.V./Kropotkin, V.V., Severnaya granitsa rasprostraneniya amfor rimskogo vremeni $\mathrm{v}$ Vostochnoy Evrope. In Kropotkin, V.V. (ed.), Mogilniky chernakhovskoy kultury (Moskva), 168-184.

KROPOTKIN/OBLOMSKIY 1991

Kropotkin, A.V., Oblomskiy, A.M., Pro etnokulturnu situatsiyu u raioni vododilu Dnipra ta Donu v 3rd-V st.n.e., Archeologia 1, 75-89.

KUKHARENKO 1952

Kukharenko, Yu.V., Novopokrovskiy mogilnik i poselenna, Archeologia 6, 33-50.

LIPKING 1979

Lipking, Yu.A., Zamoschanskaya Dyuna pod Sudzhey. In Symonovich, E.A. (ed.), Mogilniky chernakhovskoy kultury (Moskva), 5-8.

LUTSKEVICH 1948

Lutskevich, I., Materialy do karty poshirennia pamiatok kultury poliv pokhovan, Archeologia 3, 164-178.

LIUBICHEV 1999

Liubichev, M.V., Otchet ob archeologicheskih issledovaniah na territorii Kharkovskoy I Poltavskoy oblastey v 1998 g., 1999/93, Nauchnyi archiv Instituta archeologii NAN Ukrainy.

LIUBICHEV 2000
Liubichev, M.V., Cherniakhovskaya kultura dnepro-donetzkoy lesostepy: istoria issledovania i osnovnye problemy izuchenia (Kharkov: HGADTU).

\section{LIUBICHEV 2002}

Liubichev, M.V., O nekotoryh poslednih issledovaniah $v$ severovostochnoy oblasti areala cherniakhovskoy kultury, Drevneyshie obschnosti zemledelzev i skotovodov Severnogo Prichernomorya (V mys.do n.e. $-V$ v. n.e.), (Tiraspol), 381-384.

\section{LYUBICHEV 2003}

Lyubichev, M.V., K voprosu o vremeny poyavlenia pamiatnikov chernyakhovskoy kultury na dnepro-donetskom vodorazdele, Rossiyskaia archeologia 3, 71-83.

LIUBICHEV 2005A

Liubichev, M.V., Poselenia cherniakhovskoy kultury Shlyah 2 i Khalimonovka na Mzhe, Drevnosty (Kharkov), 276-287.

\section{LIUBICHEV 2005B}

Liubichev, M.V., Poyavlenie chernyakhovskoy kultury vostochnee Dnepra v svazy s sobytiamy na Dunae 20-30$\mathrm{h}$ gg.4th v.:k postanovke problemy, Arheologichniy litopis Livoberezhnoi Ukrainy 1-2, 42-49.

LJUBIČEV 2006

Ljubičev, M.V., Vojtenki 1 - eine Siedlung der Černjachov-Kultur in der Ostukraine, Eurasia Antiqua 12, 269-288.

LIUBICHEV 2006

Liubichev, M.V., ,O postroykah na selische chernyakhovskoy kultury Voytenki (po raskopkam 2004-2005 godov), Arheologichniy litopis Livobereznoi Ukrainy 2, 79-89.

LIUBICHEV 2007

Liubichev, M.V., ,Chernyakhovskaya kultura basseyna Mzhy (Severskyi Donetc) po materialam poseleniy, Verhnedonskoy archeologicheskiy sbornyk 3 (Lipetzk-sankt-Peterburg), 219-236.

LIUBICHEV 2008a

Liubichev, M.V., ,Kievo-chernyakhovskie kontakty stupeney $\mathrm{C}_{1 \mathrm{~b}}-\mathrm{C}_{2}$ na territiriy dnepro-donetzkoi lesostepy $\mathrm{v}$ svete vydelenia "gorizonta Boromlya". In: Radiush, O./Skvortsov, K. (eds.), Germania-Sarmatia I (Kaliningrad-Kursk), 44-67.

LIUBICHEV 2008b

Liubichev, M.V., ,Ob etnokulturnyh prozessah pozdnerimskogo vremeni v zone dnepro-donezkoy lesostepi ( $v$ svete issledovania arheologicheskogo kompleksa Voyitenki). In: Voronzov A.M./ Gavrituhin, I.O. (eds.), Lesnaya i lesostepnaya zony Vostochnoy Evropy $v$ epohi rimskih vlianiy $i$ Velikogo pereselenia narodov (Tula), 257-290.

LIUBICHEV 2010

Liubichev, M.V., „Horizont Boromlya“kakoblast „praslavanskoy“ kulturnoy provintsii serediny III - nachala IV v. (stupeni C1b-C2). In: Scheglova, O./M. Kazanski, M./Novakovski, W. (eds.), Germania-Sarmatia II (Kaliningrad-Kursk), 148-178.

LIUBICHEV 2011

Liubichev, M.V., Pogrebenia s pozdneskifskimi/sarmatskimi priznakami na mogilnikakh chernyakhovskoy kultury $\mathrm{v}$ dnepro-donezkoy lesostepi. In: Petrauskas, O.V./Shishkin, R.G. (eds.), Oium (Kiev), 33-52.

LIUBICHEV 2013

Liubichev, M.V., Etnokulturna istoria dnipro-donetskogo lisostepu I-V st.n.e., Avtoreferat dissertatsii...doktora istoricheskikh nauk, (Kiev).

LIUBICHEV/MYZGIN, in print

Liubichev, M.V., Myzgin, K.V., Yuzhnaya granitsa areala cherniakhovskoy kultury $\mathrm{v}$ dnepro-donetskoy lesostepi: sovremennye predstavlenia. In: Petrauskas, O.V./Shishkin, R.G. (eds.), Oium (Kiev), in print.

LIUBICHEV/MYZGIN/VARACHEVA/SCHULTZE 2014

Liubichev, M.V., Myzgin, K.V., Varacheva, K.G., Schultze, E., ,Otchet o rabote Germano-Slavyanskoy archeologicheskoy exspeditii Kharkovskogo nationalnogo universiteta imeni V.N. 
Karazina v 2012 g. Nauchniy arkhiv Instituta archeologii NAN Ukrainy.

LIAPUSHKIN 1950

Liapushkin, I.I., Pamyatniki kultury „polei pogrebeniy“ pervoi poloviny I tys.n.e. Dneprovskogo lesostepnogo Levoberezhya, Sovietskaya arheologia 13, 7-32.

LIAPUSHKIN 1961

Liapushkin, I.I., ,Dneprovskoe lesostepnoe Levoberezhie v epokhu zheleza, Materialy $i$ issledovania po archeologii USSR, 104.

MAGOMEDOV 1987

Magomedov, B.V., Chernyakhovskaia kultura Severo-Zapadnogo Prichernomoria (Kyiv: Naukova dumka).

MAGOMEDOV 1996

Magomedov, B.V., ,Obryad ingumatsii v chernyakhovskoi kulture, Tezy dopovidey ukrainskoi delegazii na VI Mizhnarodnomu kongresi slovyanskoi archeologii, 33-36.

MAGOMEDOV 1998

Magomedov, B.V., Wielbarkskie traditsii v chernyakhovskoy goncharnoi keramike, 20 łat archeołogii $w$ Masłomeczu, (Lublin, 1998), II, 143-155.

MAGOMEDOV 2001

Magomedov, B., Chernyakhovskaya kultura. Problema etnosa. (Lublin:Wydawnictwo uniwersytetu Marii Curie-Skłodowskiej).

MAKARENKO 1927

Makarenko, M., Arheologichni doslidy ta rozshuki na Pryluchyni, Korotki zvidomlena VUAK za 1926 r., 106-117.

MAKHNO 1952

Makhno, E.V., Kantemirivske poselennia ta mogylnyk kultury poliv pohovan, Archeologichni pamatki URSR 3, 231-241.

MAKHNO 1955

Makhno, E.V., Rozkopki na poselenniakh pershoi poloviny I tys.n.e.v verhniy techii Suly, Archeologichni pamatki URSR 5, 7785.

MAKHNO 1960

Makhno, E.V., ,Pamiatniki cherniakhovskoy kultury na teritorii USSR (Materialy $\mathrm{k}$ sostavleniu arheologicheskoy karty), Materialy i issledovania po archeologii USSR, 9-83.

MAKHNO 1967

Makhno, E.V., Mogilnik cherniakhovskogo tipa v gorode Sumy, Materialy i issledovania po archeologii USSR 139, 28-34.

MAKHNO 1970

Makhno, E.V., Ob osnovnyh zadachakh kartografirovania cherniakhovskoy kultury v svete vydelenia lokalnykh variantov, Kratkie soobschenia Instituta archeologii AN USSR, 60-64.

MAKHNO 1971A

Makhno, E.V., Raskopki Uspenskogo mogilnika, Archeologicjeskie issledovania na Ukraine, (Kiev), 214-218.

MAKHNO 1971B

Makhno, E.V., Tipy pohovan ta planuvannia Kompaniivskogo mogilnika, Serdeni viky na Ukraini 2 (Kiev), 87-95.

MAKHNO/SIKORSKIY 1989

Makhno, E.V., Sikorskiy, M.I., Mogilnik cherniakhovskoy kultury u s.Sosnova na Levoberezhe Dnepra, Kultura wielbarska w młodszym okrecie rzymskim, II (Lublin), 249-262.

MELNIK 1905

Melnik, E.N., Dnevnik raskopok, Trudy 12 arheologizeskogo siezda, 1, (Moskva), 703-726.

MELNIKOVSKYA/SYMONOVICH 1975

Melnikovskya, O.N., Symonovich, E.A., Rozkopki v s.Komarivtsi na Poseimi, Archeologia 15, 75-87.

MYZGIN 2008

Myzgin, K.V., Kvoprosy o vremeni postupleniya rimskikh monet v sredu chernyahovskogo naseleniya, Vestnik Kharkovskogo nacionalnogo universiteta imeni V. Karazina 40, 50-63.

MYZGIN 2009
Myzgin, K.V.,Varvarskie podrazhaniia rimskim monetam na territorii chernyakhovskoi kultury, Drevnosti 8, 90-106.

MYZGIN 2011a

Myzgin, K.V., Deaki rezultaty doslidzhen poselenna chernakhivskoi kultury bila s.Novoberecke, Archeologia 4, 7081.

MYZGIN 2011b

Myzgin, K.., Itogy issledovanyi pamatnika pozdnerimskogo vremeni vozle s.Ogultsy, Ostrogothica-Serie (Heft) 1, 26-29.

MYZGIN/BEIDIN 2012

Myzgin, K., Beidin, G., Findings of bosporan coins on the territory of Chernyakhov culture, Notae Numismaticae VII, 4579.

MYZGIN 2013a

Myzgin, K.V., Rimskie monety na territorii Dneprovskogo lesostepnogo Levoberezhia: obshaia kharakteristika, osobennosti rasprostraneniia i osnovnye problemy izucheniia, Tyragetia VII [XII].1, 355-368.

MYZGIN 2013b

Myzgin, K.V., Rimskie monety v areale cherniachovskoi kultury: problema istichnikov postupleniia, Stratum plus 4, 217-233.

MYZGIN/DYMOWSKI, in print

Myzgin, K., Dymowski, A., Pritok rimskikh denariev I-II vekov nashei ery na territoriyu cherniakhovskoi kultury $\mathrm{v}$ svete khronologicheskoi structury I territorialnogo raspredeleniia monetnykh kladov, Oium, in print.

NEKRASOVA 1985

Nekrasova, G.M., Okhoronni rozkopki chernyakhivskogo mogilnika poblysu m. Sumy, Archeologia 50, 75-80.

NEKRASOVA 1988

Nekrasova, G.M., Poselennia chernyakhovskoi kultury Khlopkov 1, Archeologia 62, 70-79.

NEKRASOVA 1990a

Nekrasova, A.M., K voprosy o nachalnom etape rasprostranenia chernyakhovskih drevnostej $\mathrm{v}$ Dneprovskom lesostepnom Levoberezhye, Okhorona i doslidzhenna pamyatok Poltavschiny, (Poltava), 150-151.

NEKRASOVA 1990b

Nekrasova, A.M., Chronologia rasprostranenia chernyakhovskoy kultury $\mathrm{v}$ Dneprovskom lesostepnom Levoberezhie, Archeologicheskie issledovania $v$ Zentralnom Chernozeme, (Belgorod), 59-60.

NEKRASOVA 1994

Nekrasova, G.M., ,Chernyakhovske poselennia bilia mista Bilopillia, Problemy rannoslovianskoi archeologii Posema, (Bilopilla), 3-4.

NEKRASOVA 2006

Nekrasova, A.M., ,Pamatniki chernyakhovskoy kultury Dneprovskogo Levoberezhya. In M.E.Levada, L.G.Samoylenko (ed.), Goty i Rim (Kiev), 87-200.

NEKRASOVA/TERPILOVSKIY 1990

Nekrasova, A.N./Terpilovskiy, R.V., Otchet o raskopkakh na poselenii i mogilnike chernyakhovskoy kultury u s. Boromla Trostyanetskogo rayona Sumskoy obl. V 1989 g., Nauchnyu arkhiv Instituta archeologii NAN Ukrainy, 1989/38a.

NUDELMAN 1982

Nudelman, A.A., ,Rimskaia moneta v mezhdureche Dnestra, Pruta i Dunaia. In Yanin, V.L. (ed.) Numizmatika antichnogo Prichenomoria (Kiev), 125-133.

OBLOMSKIY 1990

Oblomskiy, A.M., ,Pamyatniki "zarubinetskoy linii razvitiya" na vodorazdele Dnepra i Dona v I-V vv.n.e., Archeologicheskie issledovania v Zentralnom Chernozeme, (Belgorod), 61-63.

OBLOMSKIY 1991

Oblomskiy, A.M., Etnicheskie prozessy na vodorazdele Dnepra $i$ Dona v I-V vv.n.e. (Moskva-Sumy). 


\section{OBLOMSKIY 1997}

Oblomskiy, A.M., ,O vzaimootnoshenii kievskogo i chernyakhovskogo naselenia na vodorazdele Dnepra i Dona, Problemy pohodzhenna ta istorychnogo pozvitku slovyan, (KiyvLviv), 63-72.

OBLOMSKIY 1999a

Oblomskiy, A.M., O vremeni poyavleniya chernyakhovskogo naselenia na territorii Dneprovskogo Levoberezhia. In M.E. Levada (ed.), Sto let chernyakhovskoy kultury (Kiev), 26-38.

OBLOMSKIY 1999b

Oblomskiy, A.M., Tipy pohovan na chernyakhivskomu mogilniku Kompaniytsy (etnokulturna interpretatsia), Archeologia 4, 76-88.

OBLOMSKIY 2001-2002

Oblomskiy, A.M., Novyi chernyakhovskiy pamyatnik na territorii Rossii, Stratum plus 5, 27-52.

OBLOMSKIY 2002

Oblomskiy, A.M., Dneprovskoe lesostepnoe Levoberezhe $v$ pozdnerimskoe i gunnskoe vremya (Moskva: Nauka).

OBLOMSKIY 2009

Oblomskiy, A.M., O vremeni i kharaktere rasprostranenia chernyakhovskoy kultury na territorii Dneprovskogo Levoberezha (nashi raznoglasia). In: Myzgin, K. (ed.), Ostrogothica (Ckharkov), 264-287.

OBLOMSKIY/TERPILOVSKIY 1991

Oblomskiy, A.M., Terpilovskiy, R.V., Srednee Podneprove i Dneprovskoye Levoberezhye v pervye veka nashey ery (Moskva: Nauka).

PAMYATNIKI... 2007

Pamyatniki kievskoy kultury v lesostepnoy zone Rossii (III nachalo $\mathrm{V}$ v.n.e.), Ranneslavyanskiy mir. Archeologia slavyan $i$ ih sosedey 10.

PETRAUSKAS/SHISHKIN 2010

Petrauskas, O.V./Shishkin, R., G., Mogilnik i poselenie $\mathrm{u}$ s.Velikaya Bugaevka $\mathrm{i}$ ih mesto $\mathrm{v}$ sisteme drevnostey pozdnerimskogo vremeni i epohy Velikogo pereselenia narodov v Srednem Podneprovye. In: A.M.Voronzov, I.O.Gavritukhin (ed.), Lesnaya i lesostepnaya zony Vostochnoy Evropy $v$ epohi rimskih vlianiy $i$ Velikogo pereselenia narodov 2, (Tula), 19-32.

PETRAUSKAS/ZINDROVSKAYA 2002

Petrauskas, O.V., Zindrovskaya, L.A., Nahodki chernyakhovskoy kultury vblizi Zhovnino (Kiev).

PETRENKO 1983

Petrenko, E.N., Otchet ob issledovaniah Chernyakhovskoy ekspedizii v 1982 g. Nauchnyi arkhiv Instituta archeologii NAN Ukrainy, 1982/113

PETRENKO 1991

Petrenko, E.N., Novye mogilniki chernyakhovskoy kultury v basseyne Severskogo Donca, Archeologia slavyanskogo yugovostoka, (Voronezh), 10-26.

PRIKHODNYUK 1998

Prikhodnyuk, O.M., Penkovskaya kultura. (Voronezh: Voronezhski universitet)

RADIUSH 2008

Radiush, O.A., Novye pamyatniki III-V vv. v Kurskom Poseyme, In: Gavrituhin, I.O. (ed.), Lesnaya i lesostepnaya zony Vostochnoy Evropy $v$ epohi rimskih vlianiy $i$ Velikogo pereselenia narodov (Tula), 181-208.

RADIUSH 2010

Radiush, O.A., Issledovania poselenia 3rd-4th vv.n.e. u pos. im. Karla Libknehta (Peny) v Kurskom Poseme. In: Scheglova, O./Kazanski, M./Novakovski, W. (eds.), Germania-Sarmatia II (Kaliningrad-Kursk), 179-213.

RADIUSH 2011A

Radiush, O.A., Mogilnik u pos. Im.Karla Libknehta (Peny). In Petrauskas, O.V./Shishkin, R.G. (eds.) Oium (Kiev), 233-242.

\section{RADIUSH 2011B}

Radiush, O.A., Severo-vostochnaya graniza chernyakhovskoy kultury po dannym polevyh issledovanyi 2005-2010 gg., Ostrogothica-Serie (Heft) 1, 30-32.

RIKMAN 1975

Rikman, E.A., Etnicheskaia istoriya Podnestrovia i prilegayushego Podunavia v pervykh vekakh nashei ery (Moskva: Nauka).

ROMANOVA 1989

Romanova, G.A., Chernyakhovskie poselenia u s. Artyukhovka, Problemy archeologii Sumschiny, (Sumy), 58-60.

RUDINSKIY 1928

Rudinskiy, M., Archeologichni zbirki Poltavskogo muzeyu, Poltavskyi derzhavnyu musey im.V.G.Korolenka, 1, (Poltava), 52-54. RUDINSKIY 1930

Rudinskiy, M. Ya., Kantamyrivski mogily rymskoy doby, Zapisky VUAK 1, 127-158.

RUTKOVSKAYA 1979

Rutkovskaya, L.M., Archeologicheskie pamyatniki 4th-VI vv. v rayone Kremenchugskogo morya (Ukraina), Slovenska archeologia 27, 317-364.

SCHULTZE 2009

Schultze, E., Gefäßbeigaben in Kindergräbern der ČernjachovKultur-zu einem Grab aus Sumy-Sad (Ostukraine). In: Myzgin, K. (ed.), Ostrogothica (Ckharkov), 165-173.

SHALOBUDOV/ANDROSOV/MUHOPAD 1983

Shalobudov, V.N./Androsov, V.A./Muhopad, S.E., Raskopki kurganov u s. Dmukhaylovka, Drevnosti stepnogo Podneprovya, (Dnepropetrovsk), 19-27.

SHAROV 2007

Sharov, O., Keramicheskiy kompleks nekropolia Chatyr-Dag. Khronologiya kompleksov s rimskimi importami (krasnolakovaia keramika) (Sankt-Peterburg: Nesotr-Istoriya).

SHRAMKO 1979

Shramko, B.A., Mogilnik u s. Pavlukovka. In: Symonovich, E.A. (ed.), Mogilniky chernakhovskoy kultury, (Moskva), 9-12.

SHRAMKO/DYACHENKO 1978

Shramko, B.A., Dyachenko, A.G., Otchet ob archeologicheskih issledovaniakh $\mathrm{V}$ zone sooruzhenia Muromskogo vodokhranilischa v 1978 g., Nauchnyu archiv Instituta archeologii NAN Ukrainy, 69.

SHUKIN 1979

Shukin, M.B., K voprosu o verhney chronologicheskoy granize chernyakhovskoy kultury, Kratkie soobschenia Instituta archeologii AN USSR, 158, 17-22.

SHUKIN 2005

Shukin, M.B., Gotskiy put. Goty, Rim i cherniakhovskaia kultura (Sankt-Peterburg: Philologocheskiy fakultet SanktPeterburgskogo universiteta)

SHUKIN/SHAROV 2000

Shukin, M.B., Sharov, O.V., K probleme finala chernyakhovskoy kultury, Stratum plus 4, 369-383.

SIMONENKO 2001

Simonenko, A.V., Evropeyskie alany i alany-tanaity v Severnom Prichernomorye, Rossiyskaia archeologia 4, 77-91.

SIMONENKO 2012

Simonenko, A.V., Pozdnesarmatskoe pogrebenie v Tsentralnom Donbasse, Kon, zoloto i chelovek, (Kiev), 227-240.

SKIRDA 2000

Skirda, V.V., Doslodzhennia novogo selischa chernyakhivskoi kultury poblizu m. Bogoduhova, Archeologichni doslidzhenna $v$ Ukrainy 1999 r., 148.

SKIRDA 2002

Skirda, V.V., Rozkopky poselenna chernyakhivskoi kultury, Archeologichni doslidzhenna v Ukrainy 2001 r., 242-243.

SPITSYN 1948

Spitsyn, A.A., Polya pogrebalnyh urn, Sovetskaya archeologia 10, 
53-74.

STEPANOVICH/SUPRUNENKO 1994

Stepanovich, S.P., Suprunenko, O.B., Ostanniy poliovyi sezon Mykoli Stana, Poltavskiy archeologichniy zbirnyk 2, 21-25.

SUPRUNENKO/LYAMKIN/SIDORENKO 2011

Suprunenko, O.B./Lyamkin, V.V./Sidorenko, O.V., Unikalnyi pohovalnyi kompleks pochatku gunnskogo chasu $\mathrm{v}$ kurgani $\mathrm{v}$ okolytzyach Komsomolska, Archreologia i davnia istoria Ukrainy 6, 168-176.

SUPRUNENKO/SHERSTYUK 2006

Suprunenko, O.B., Sherstyuk, V.V, Novi archeologichni doslidzhennia na Kremenchugchiny (Kiev-Poltava).

SUPRUNENKO/SHERSTYUK 2007

Suprunenko O.B., Sherstyuk V.V, Pamyatki archeologii na teritorii Galeschinskogo rodovscha zaliznyh kvarzytiv na Poltavschiny (Kiev-Poltava).

SYMONOVICH 1964

Symonovich, E.A., Severnaya graniza pamyatnikov chernyakhovskoy kultury, Materialy i issledovania po archeologii USSR 116, 7-43.

SYMONOVICH 1974a

Symonovich, E.A., Novye otkrytia $\mathrm{v}$ selischakh Afdeevo i Vorobiovka 2 vozle g. Kurska, Pannesrednevekovye vostochnoslavyanskie drevnosti, (Leningrad), 153-158.

SYMONOVICH 1974b

Symonovich, E.A., Poselenie Vorobyovka 2 v Kurskoy oblasti, Kratkie soobschenia Instituta archeologii AN USSR 140, 76-83.

SYMONOVICH 1983

Symonovich, E.A., Pivnichno-skhidne pogranicha pamatok chernyakhivskoi kultury, Archeologia 44, 71-85.

SYMONOVICH 1984

Symonovich, E.A., Razvitie kultury chernyakhovskikh plemen Levoberezhya Dnepra (po materialam lepnoi keramiki), Kratkie soobschenia Instituta archeologii AN USSR 140, 73-81.

SYMONOVICH 1986

Symonovich, E.A., Rannesrednevekovoe poselenie Tazovo pod Kurskom, Sovetskaya archeologia 4, 183-193.

SYMONOVICH 1990

Symonovich, E.A., Bukreevka 2 - selische vtoroy chetverti I tys.n.e. vozle Kurska. In: Terpilovskyi, R.V. (ed.), Materialy $i$ issledovania po archeologii Dneprovskogo Levoberezhya, (Kursk), 1990, 78-110.

SYMONOVICH 2001-2002

Symonovich, E.A., Poselenie Kamenevo 2 pod Kurskom, Stratum plus 4, 370-383.

SYMONOVICH/KRAVCHENKO 1983

Symonovich, E.A., Kravchenko, N.M., Pogrebalnye obryady plemen chernyakhovskoy kultury, Svod arkheologicheskikh istochnikov D1-22.

SYMONOVICH/SOKOL 1978

Symonovich, E.A., Sokol, K.F., Poselenia chernyakhovskoy kultury u s. Snagost v Poseyme, Archeologicheskye otkrytia 1977 g., 88.

\section{TERPILOVSKIY 1984}

Terpilovskiy, R.V., Rannye slavyane Podesenya $v 3 r d-V v v$. (Kiev: Naukova dumka).

TERPILOVSKIY 2000

Terpilovskiy, R.V., Kievskaya i chernyakhovskaya kultury. Problema kontaktov, Stratum plus 4, 303-311.

TERPILOVSKIY 2002

Terpilovskiy, R.V., Do problemy kontaktiv mizh kiyvskoy ta chernyakhivskoy kulturamy na ranniomu etapi rozvytku, Archeologia 3, 18-26.

TERPILOVSKIY 2004a

Terpilovskyi, R.V., Glevaha i Boromlya (k voprosu o haraktere kontaktov mezhdu kievskoy i chernyakhovskoy kulturamy na rannem etape), Europa Barbarica. Monumenta studia Gothica, (Lublin), 465-475.

TERPILOVSKIY 2004b

Terpilovskiy, R.V., Slavyane Podneprovya v perv. pol. I tys. (Lublin: Wydawnictwo uniwersytetu Marii Curie-Skłodowskiej). TERPILOVSKIY 2008

Terpilovskiy, R.V., Novye pamyatniki 3rd-V vv. v SeveroVostochnoi Ukraine, Trudy II (XVIII) Vserossiyskogo archeologicheskogo syezda $v$ Suzdale, 2, 297-299.

TERPILOVSKIY/ABASHINA 1992

Terpilovskiy R.V./Abashina N.S., Pamyatniki kievskoy kultury (Kiev: Naukova Dumka).

TIKHOMIROV/TERPILOVSKYI 1990

Tikhomirov, N.A./Terpilovskyi, R.V., Poselenia Gochevo 1 i 2 na r. Psiol, Materialy i issledovania po archeologii Dneprovskogo Levoberezhya, (Kursk), 1990, 43-77.

TRETYAKOV 1970

Tretyakov, P.N., U istokov drevnerusskoy narodnosti, Materialy $i$ issledovania po archeologii USSR, 179.

BURSCHE 2013

Bursche, A., The Battle of Abritus, the Imperial treasury and aurei in Barbaricum, Numismatic Cronicle 173, 151-169.

ZHAROV/TERPILOVSKIY 2011

Zharov, G.V, Terpilovskiy, R.V., Novy pamatki Chernyakhivskoi kultury u mezhyrichi Udaiu ta Suly, Chernyakhivska kultura. In O. V. Petrauskas, R-G.Shishkin (ed.) Oium (Kiev), 166-177.

ZHURKO 1994

Zhurko, A.I., Pamiatniki cherniakhovskoj kultury v lesostepnom Dneprovskom Levoberezhe, Rossiyskaia archeologia, 4, 207-218.

ZINKOVSKAYA 1997

Zinkovskaya, I.V., Naselenie lesostepnogo Dnepro-Donezkogo mezhdurecha vo vtoroj-tretey chetverti I tys. n.e. (po materialam pogrebalnykh kompleksov s krematsiyamy), Avtoreferat dissertazii... kandidata istoricheskih nauk (Voronezh). 


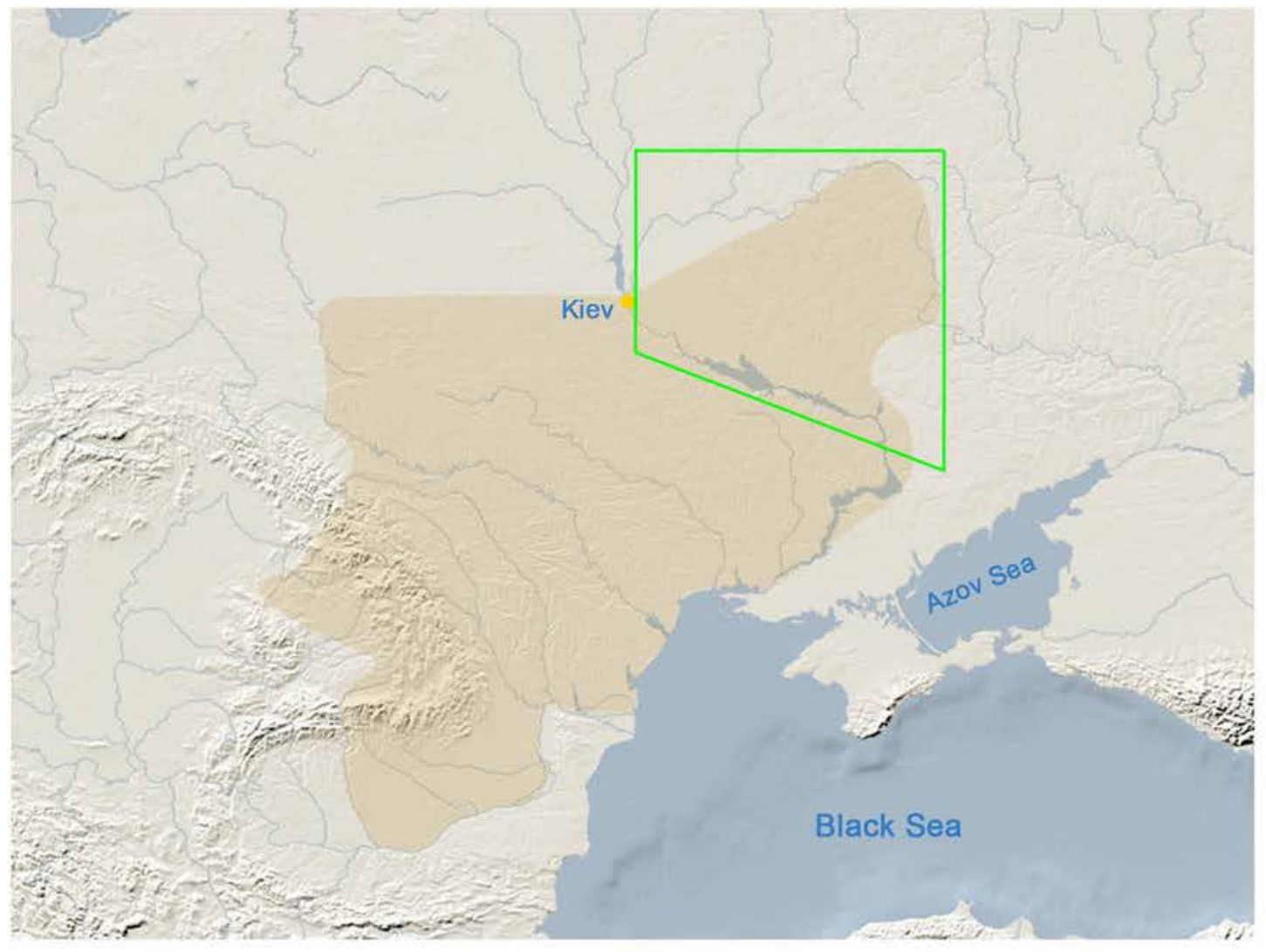

Fig.1. Location of the "Dnieper-Donets forest-steppe" in the area of Chernyakhiv Culture. 


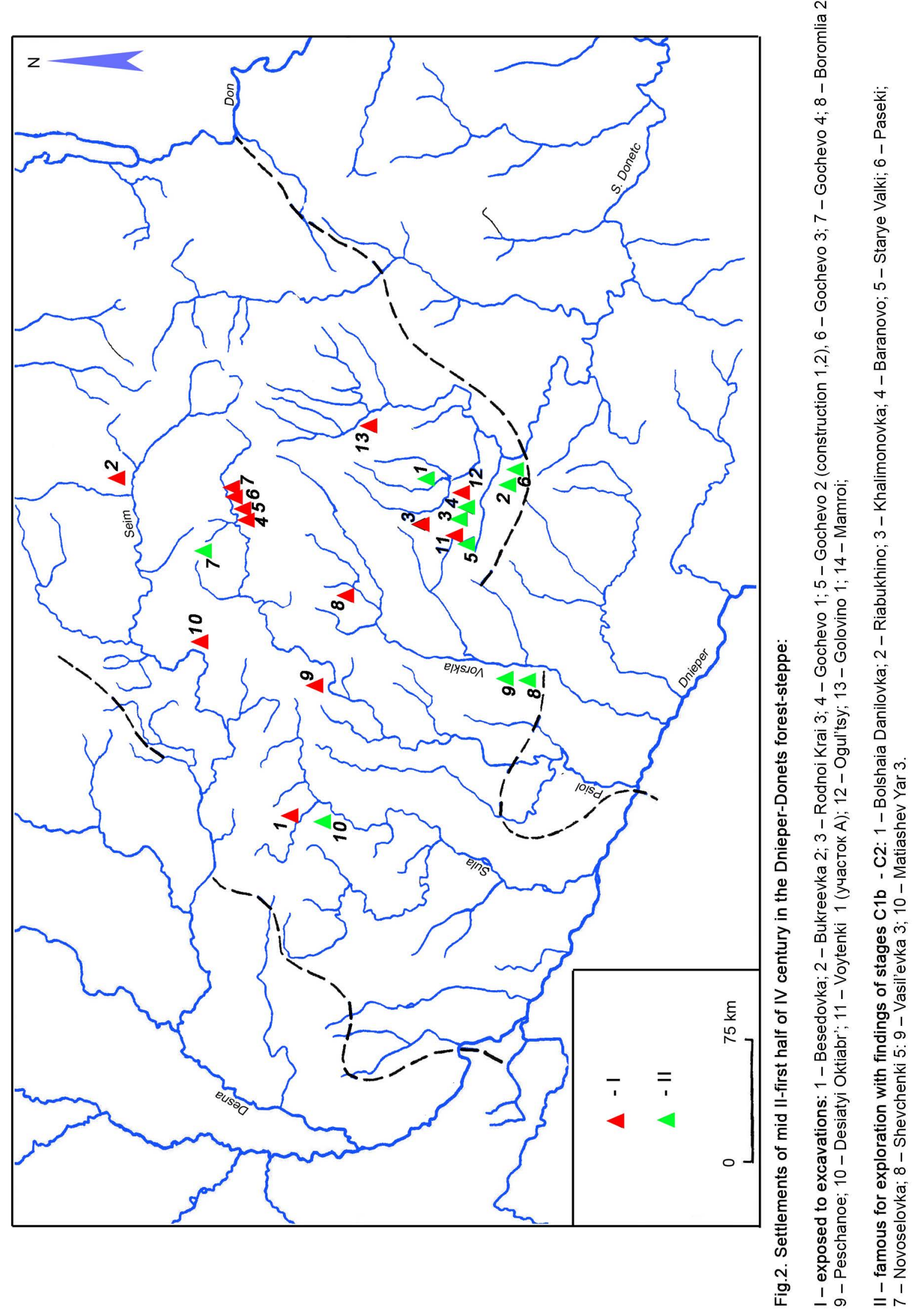



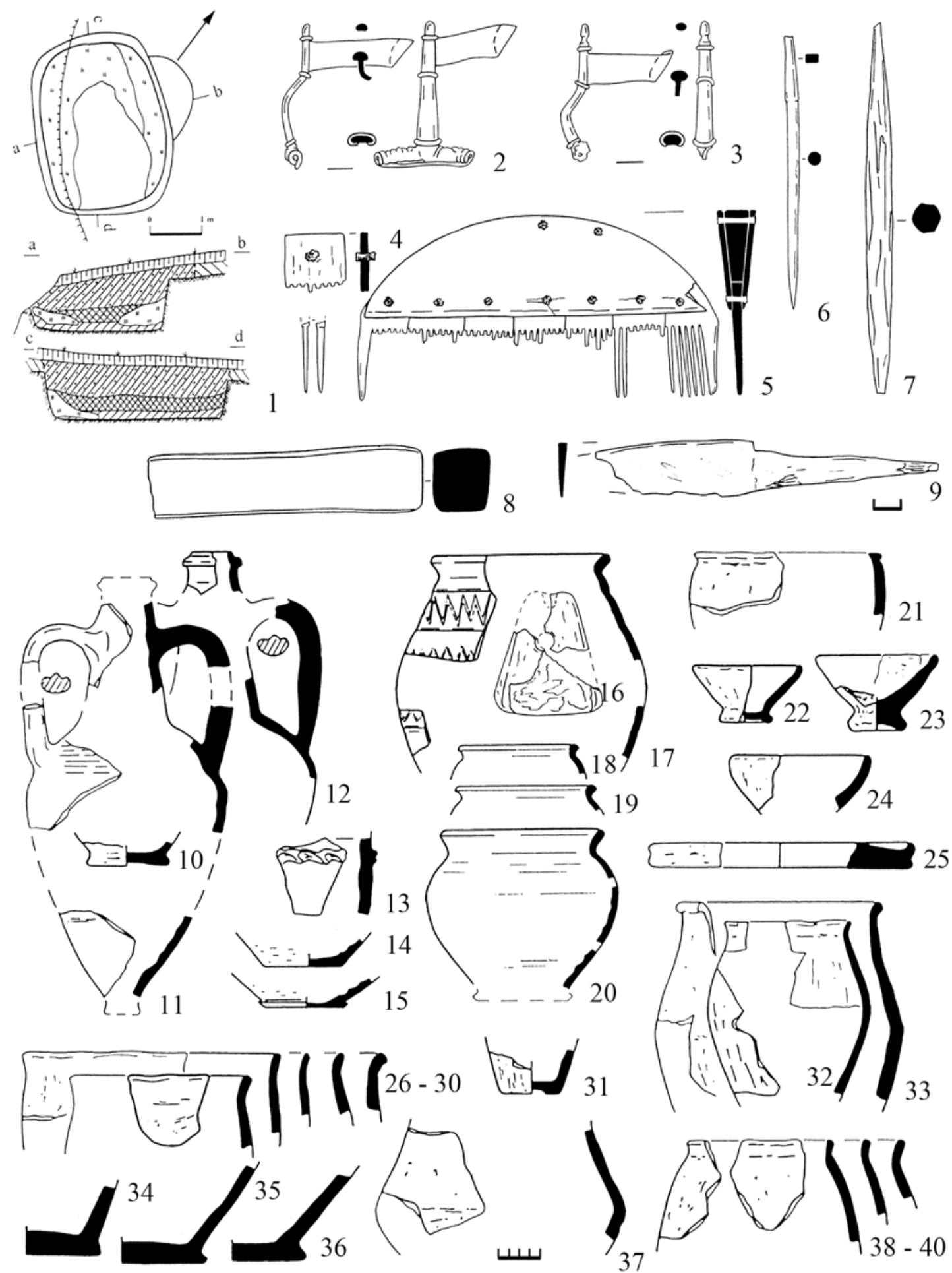

Fig.3. Horizon of Boromlia: construction 1 of settlement of Boromlia 2 (1) and its findings:

2, 3 - bronze fibulae; 4- fragment of bone comb; 5 - bone comb; 6 - bone "stylos"; 7 - iron awl; 8 - strickle; 9 - fragment of iron knife; 11,12 - glass clay amphorae; $10,13-20$ - pottery; $21-40$ - moulded ceramics (NEKRASOVA 2006, ris. 20, 21). 

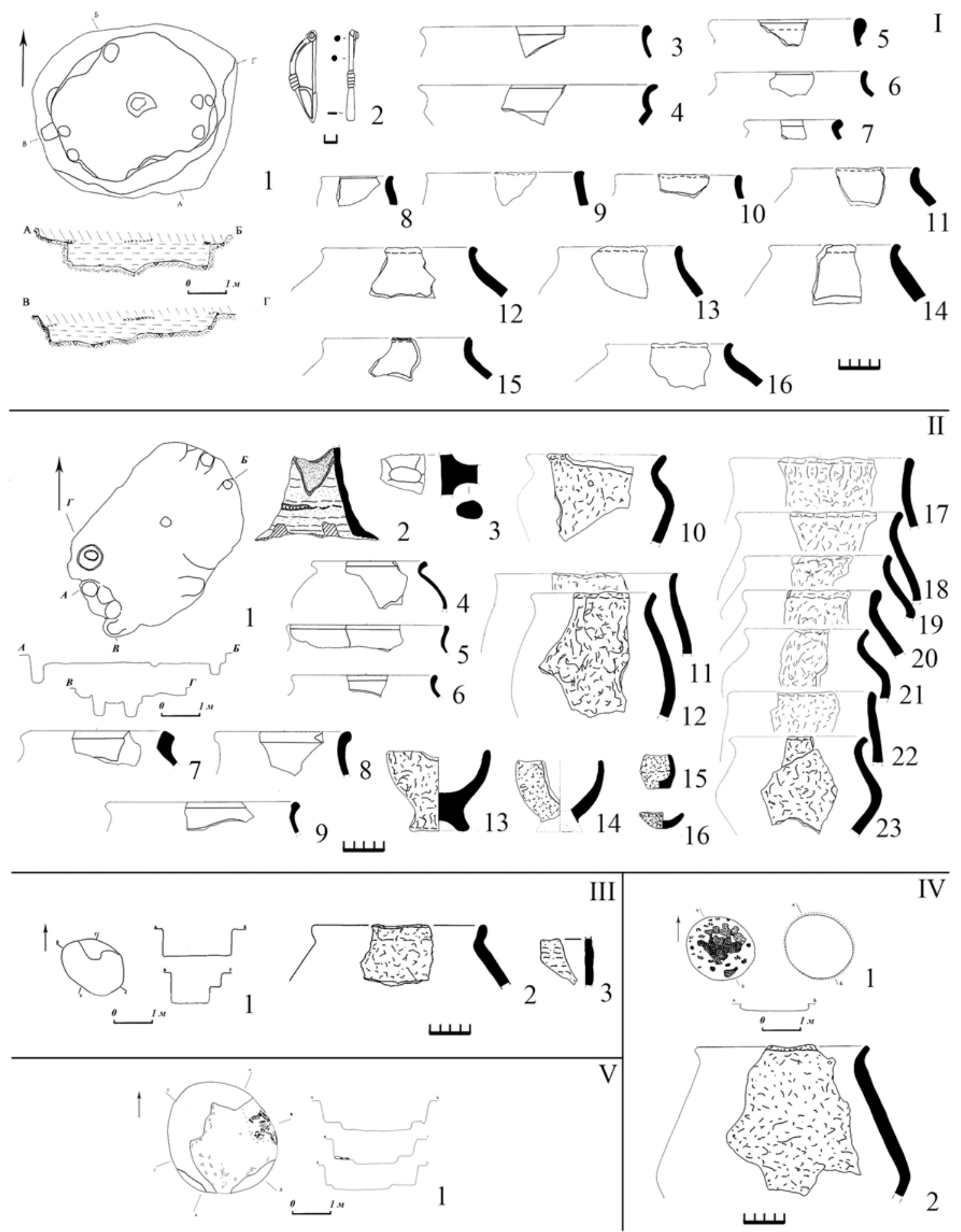

Fig.4. Horizon of Boromlia: materials from the settlement of Voytenki 1, area "A":

I - construction 2/2 (1) and its findings: 2 - bronze fibula; 3 - 7 - pottery; 8 - 16 - moulded ceramics;

II - construction 4 and its findings: 2,3 - fragments of glass clay amphorae; 4 - 9 - pottery; 10 - 23-moulded ceramics;

III - construction 11 (1) and its findings: fragment of moulded pot (2), fragment of amphora's side (2);

IV - construction 17 (1) and fragment of moulded pot (2);

$V$ - construction $21(1)$. 


\section{Studies

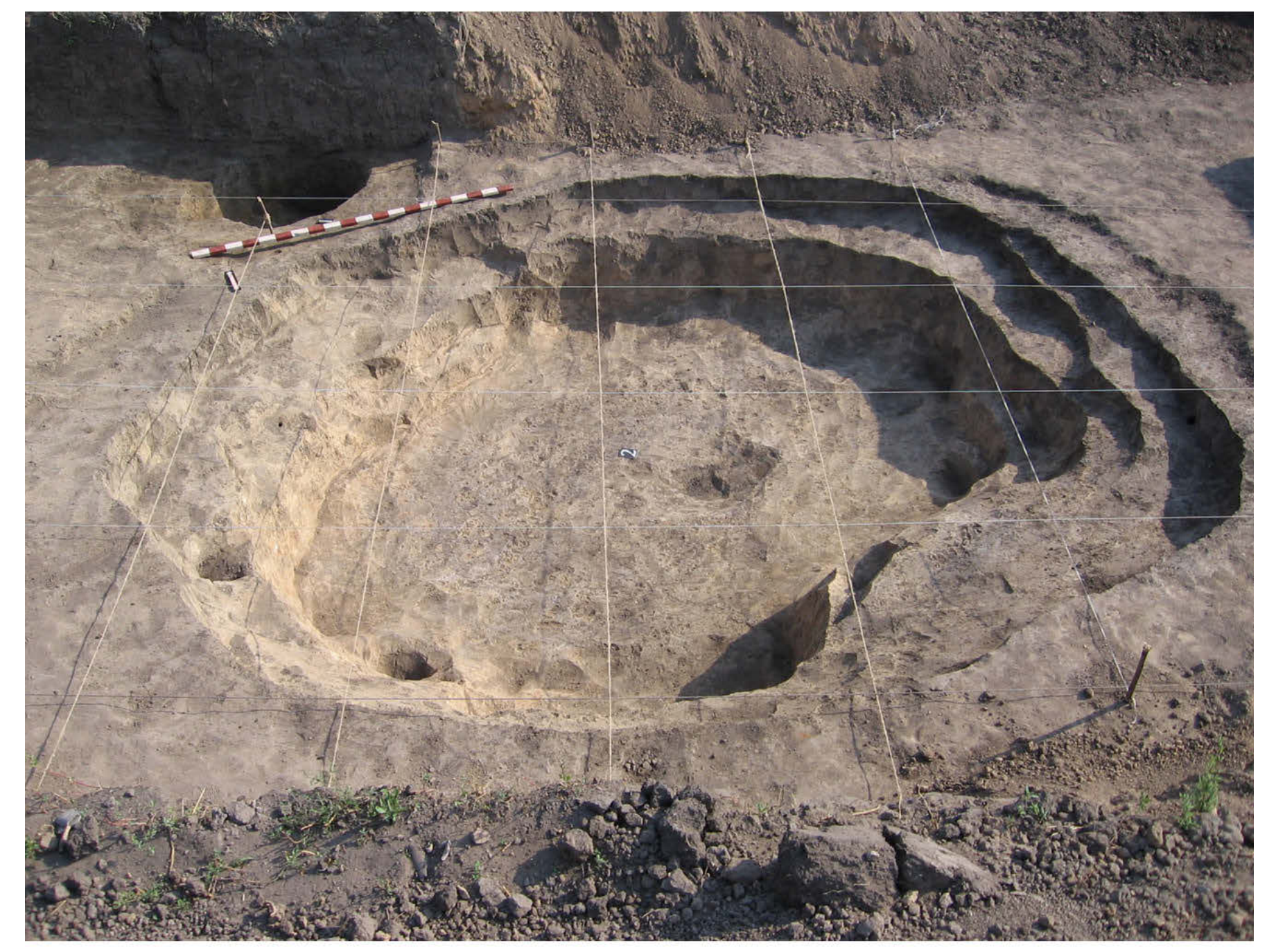

Fig.5. Horizon of Boromlia: depressed construction 2/2 on the area "A" in the settlement of Voytenki 1.

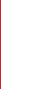

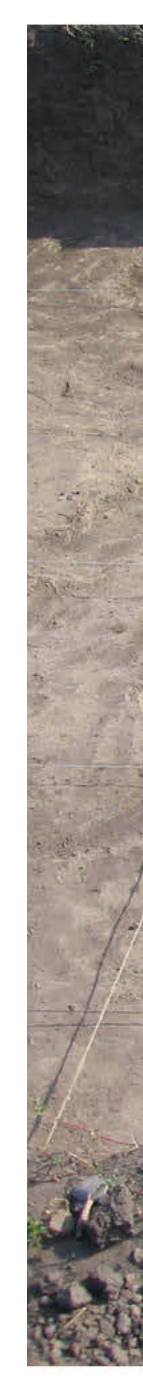

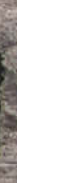

.

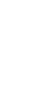

(2) 

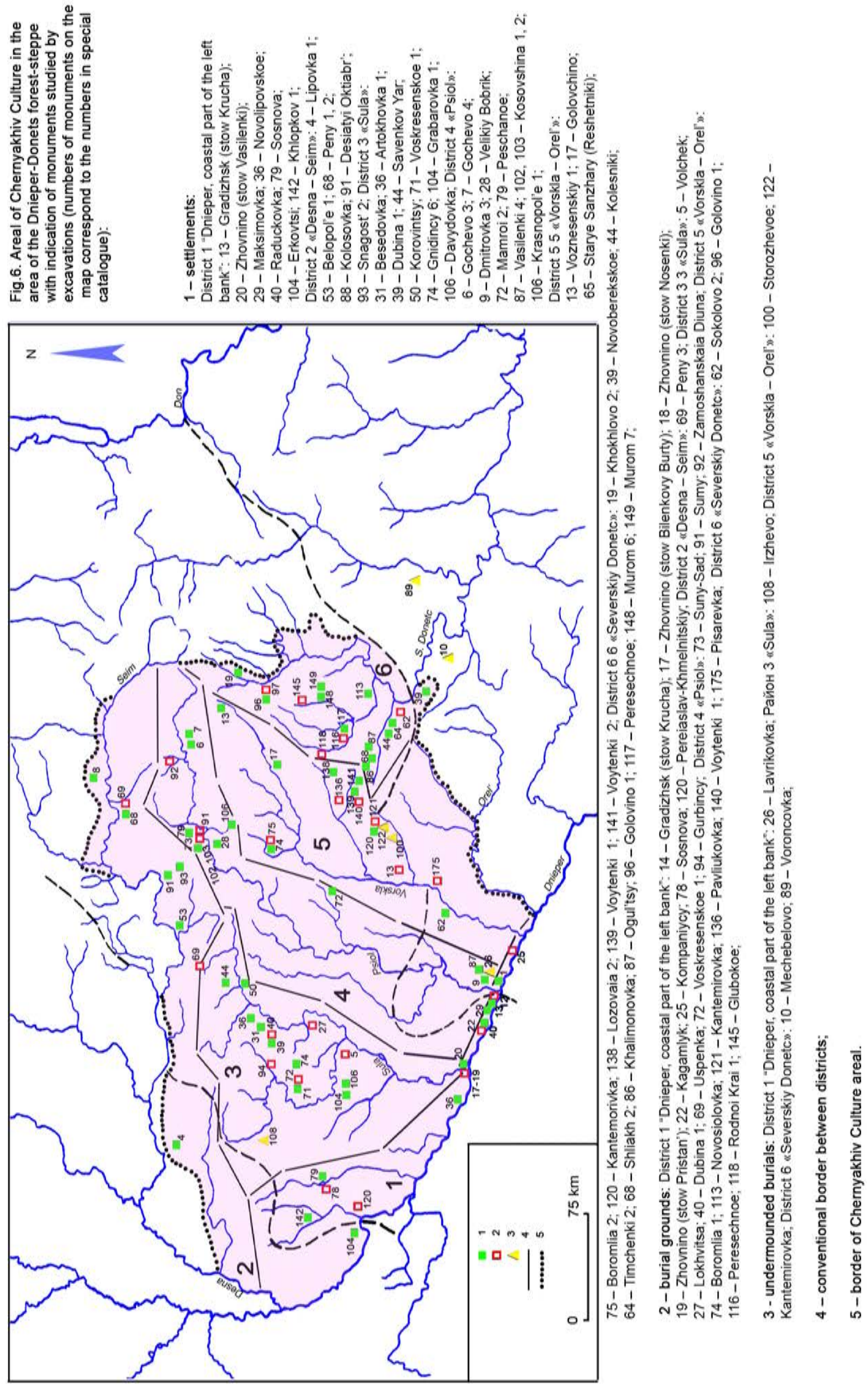


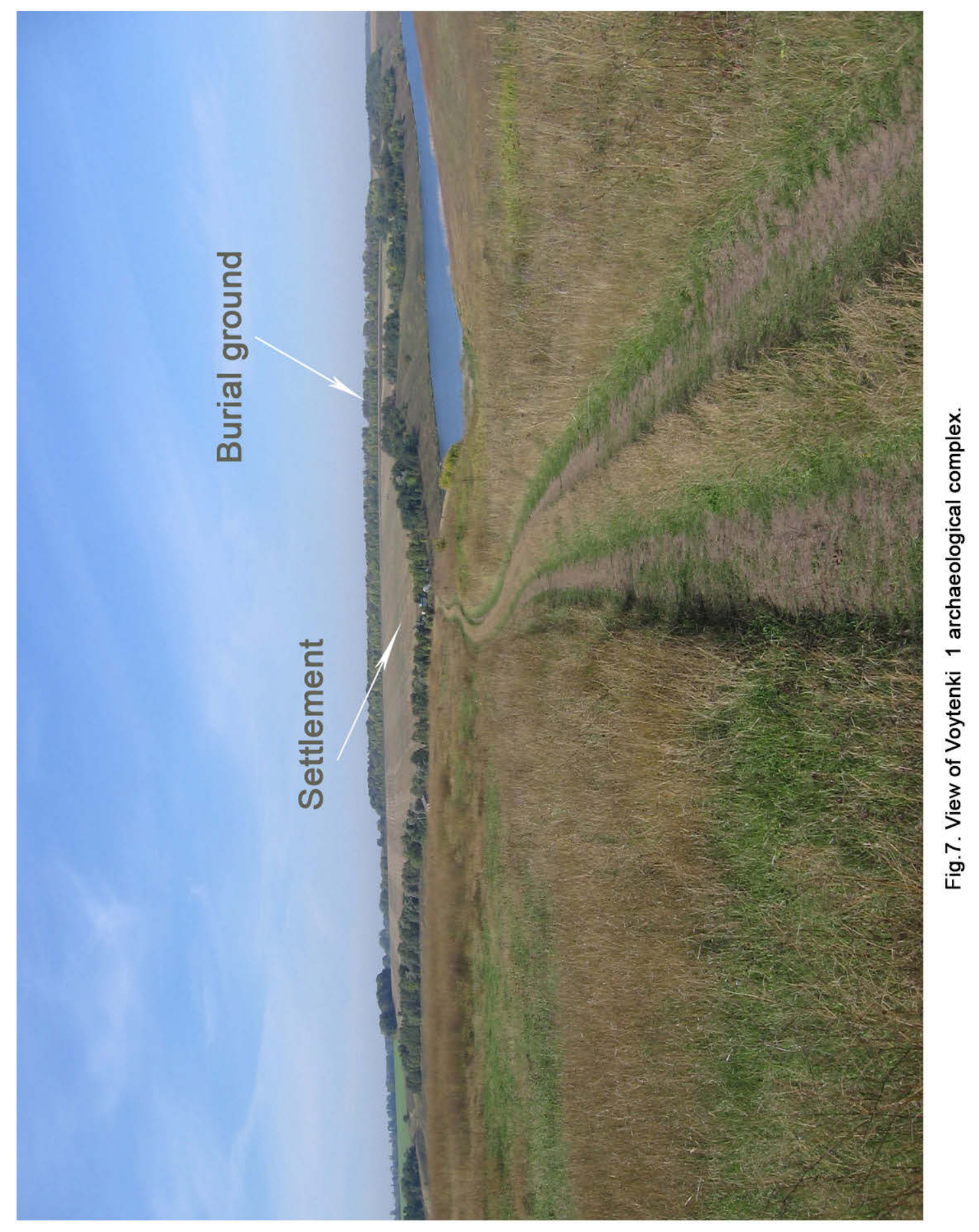



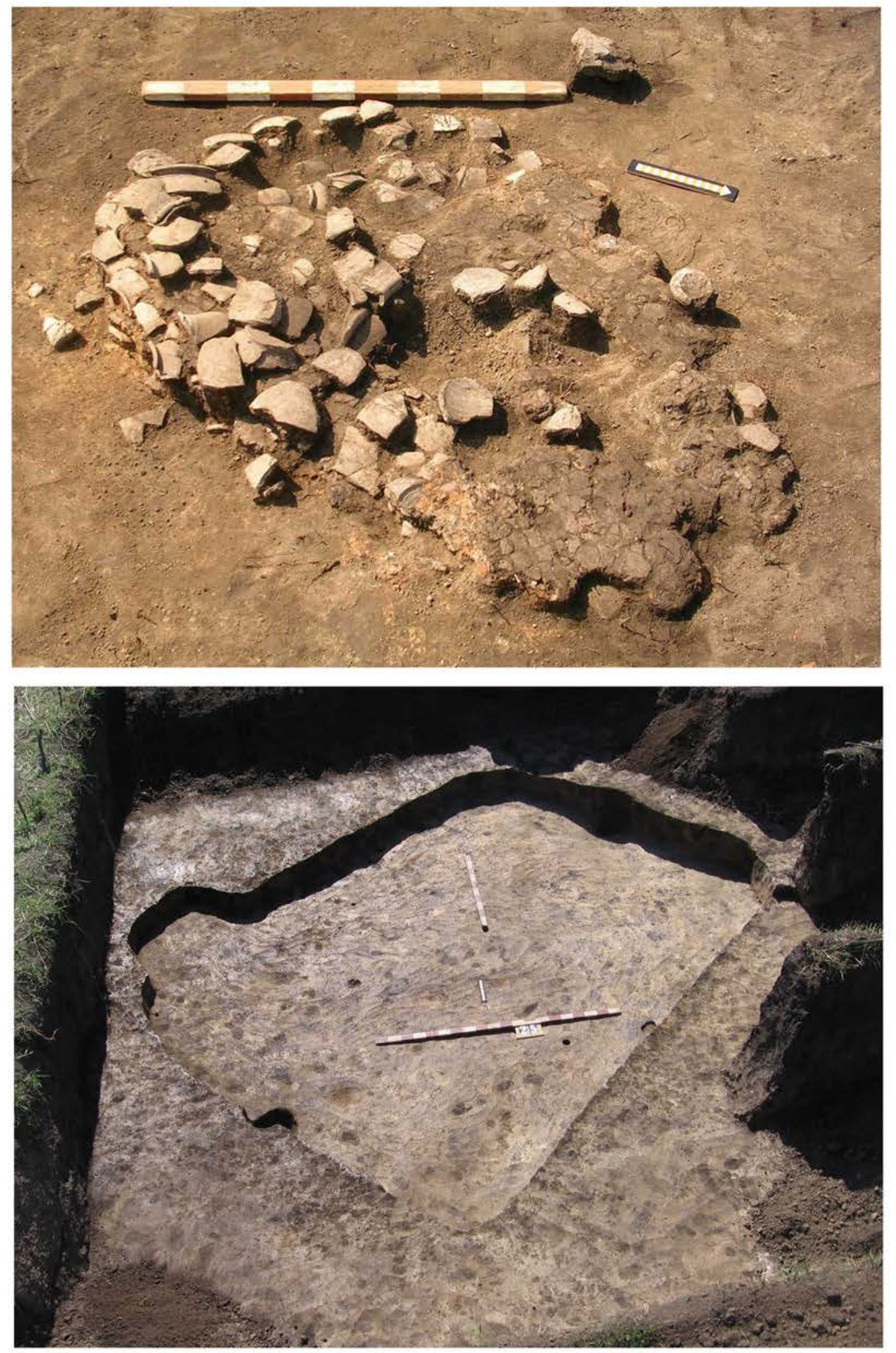

Fig.8. Chernyakhiv Culture: hearth in the above-ground framed wattle and daub construction (1), depressed construction (2). Settlement of Voytenki 1, area "A". 


\title{
Studies
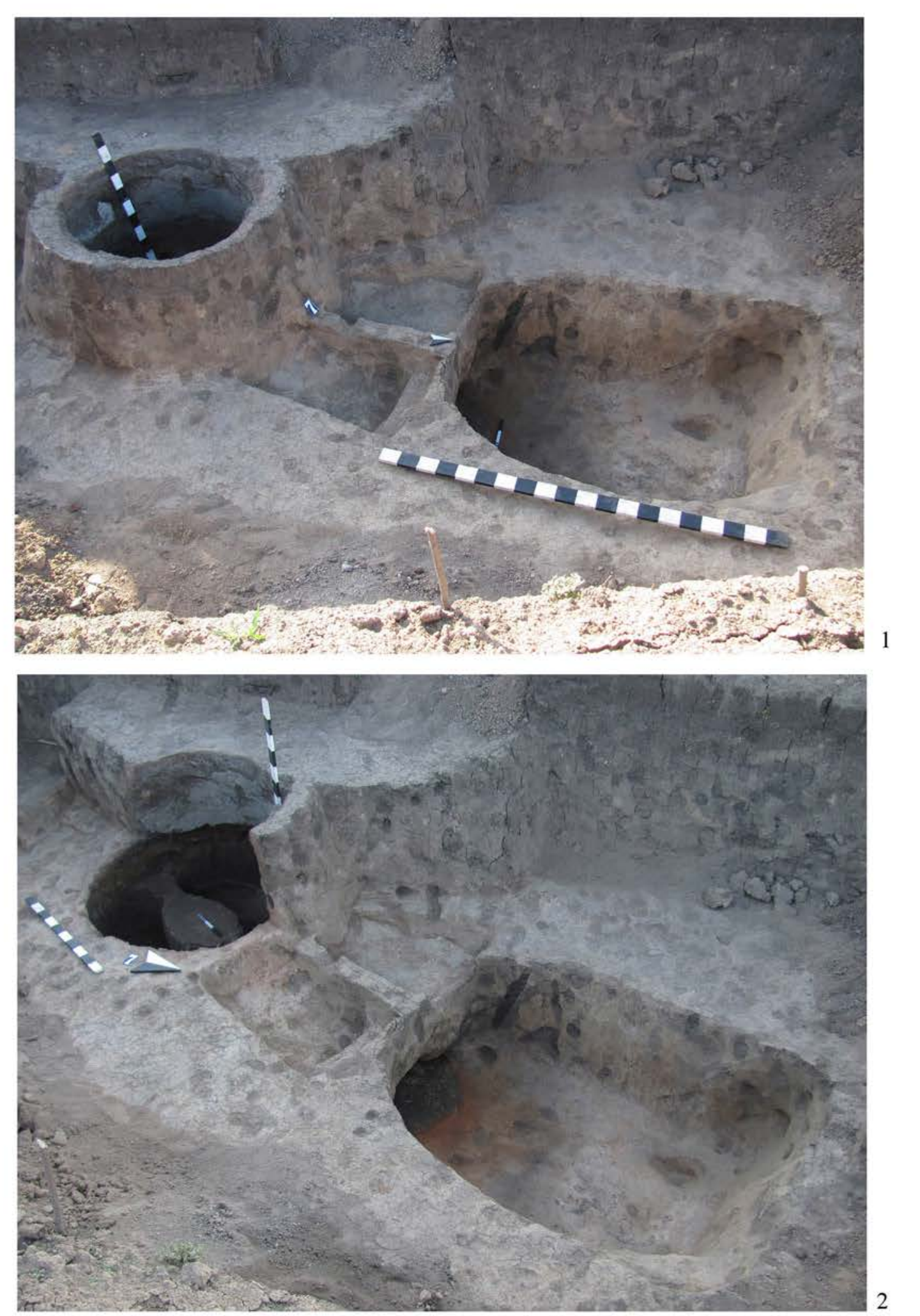

\begin{abstract}
Fig.9.Chernyakhiv Culture: kiln (object 7, parcel A, area "B" of Voytenki 1 settlement).
\end{abstract} (1)

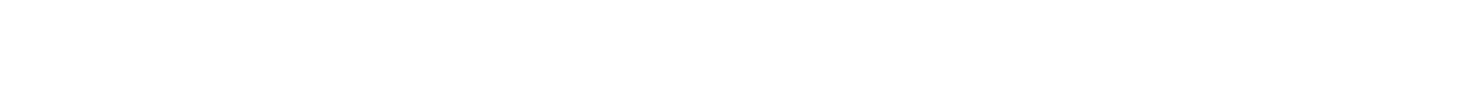

(1)

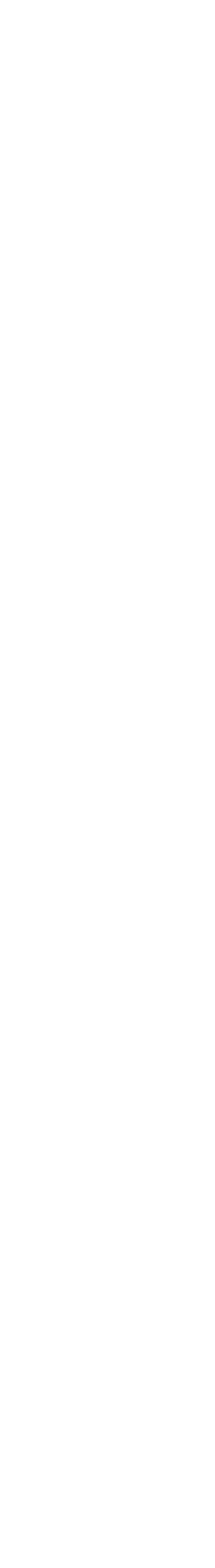



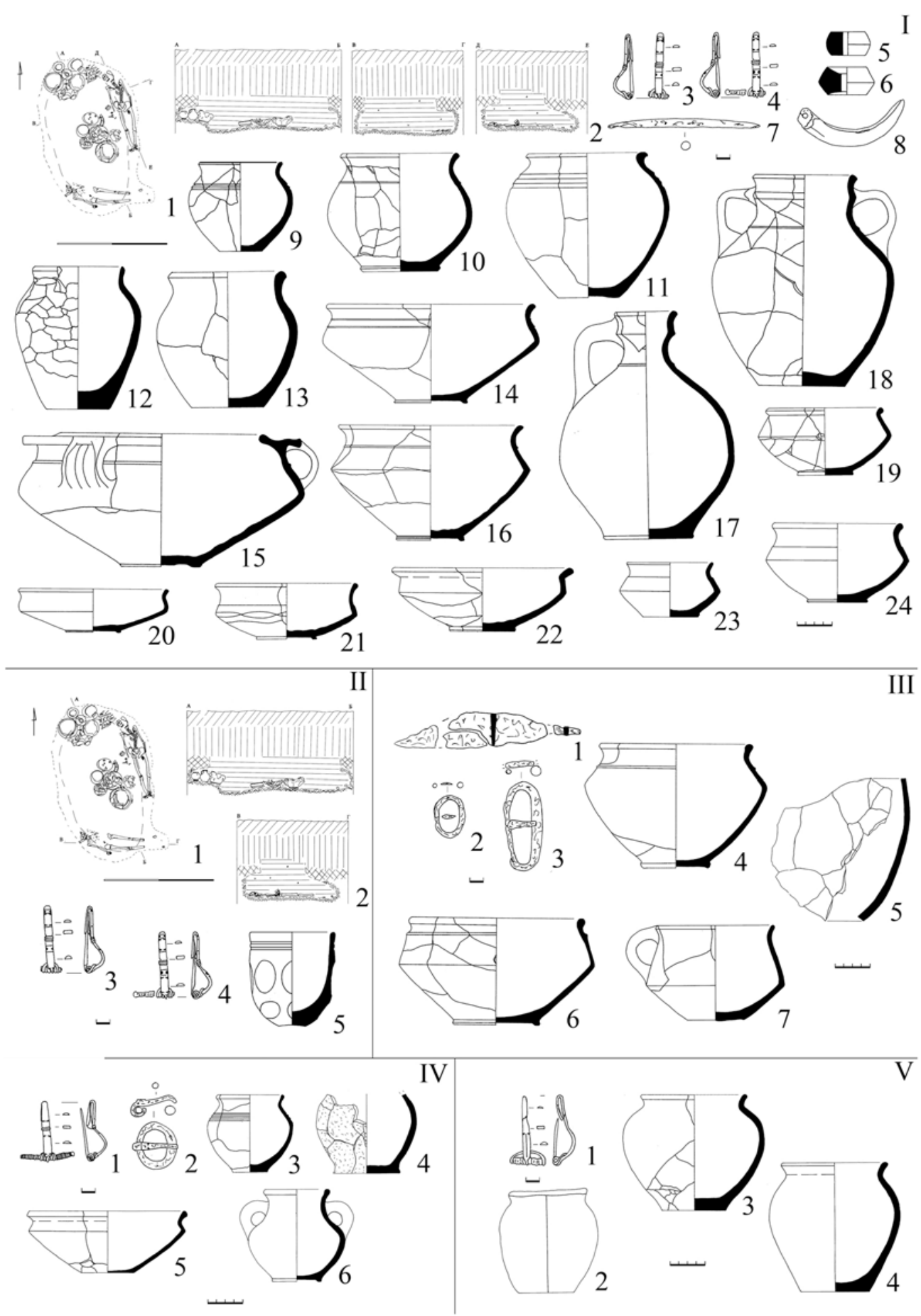

Fig.10. Chernyakhiv Culture: Voytenki burial ground:

I - burial $86 / 1$ of Voytenki burial ground $(1,2)$, its inventory $(5-24)$;

II - burial $86 / 2$ of Voytenki burial ground $(1,2)$, its inventory $(3-5)$;

III - burial 93: inventory;

IV - burial 92: inventory;

$\mathrm{V}$ - burial 94 : inventory. 


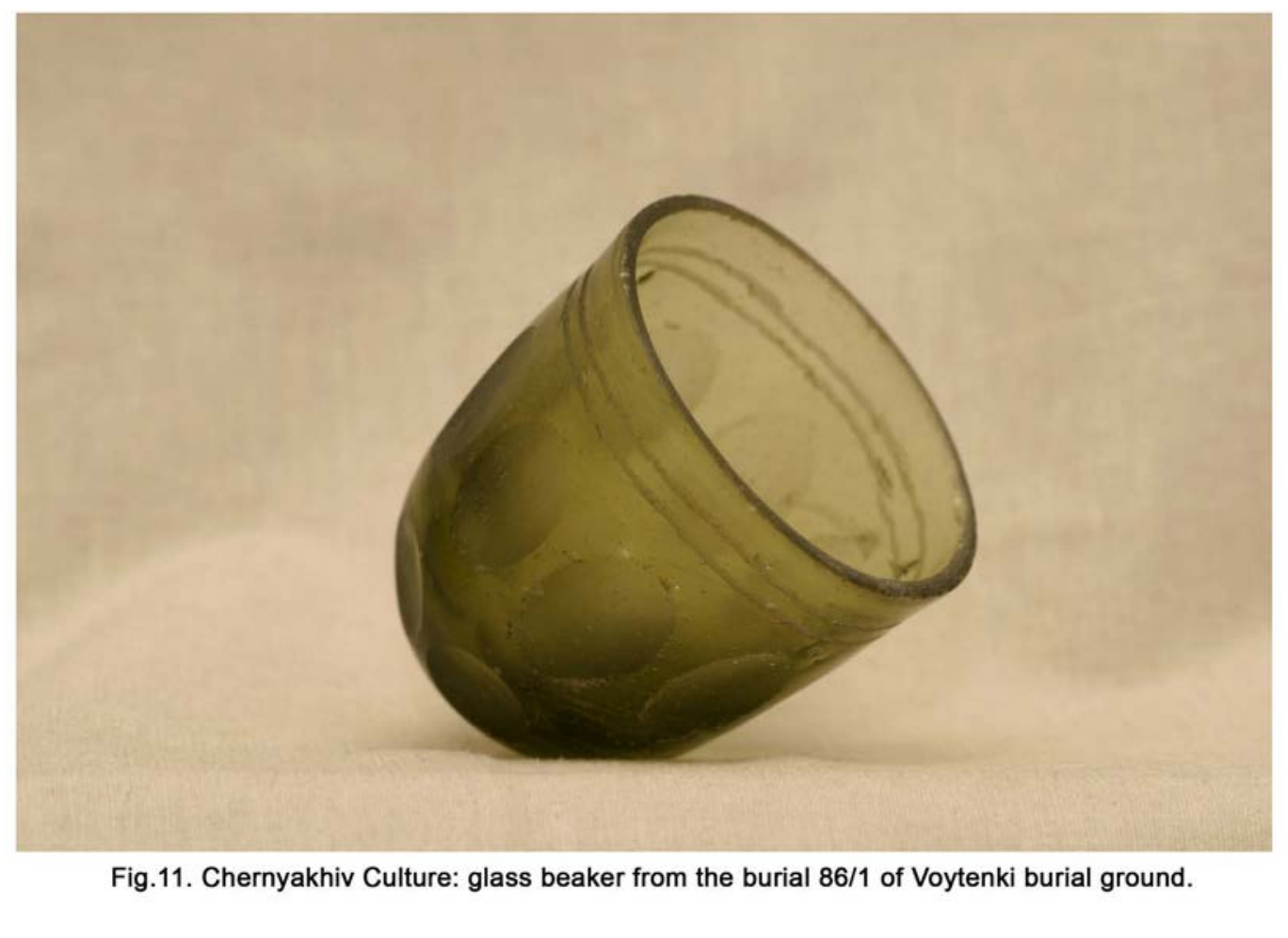

Fig.11. Chernyakhiv Culture: glass beaker from the burial $86 / 1$ of Voytenki burial ground.

I

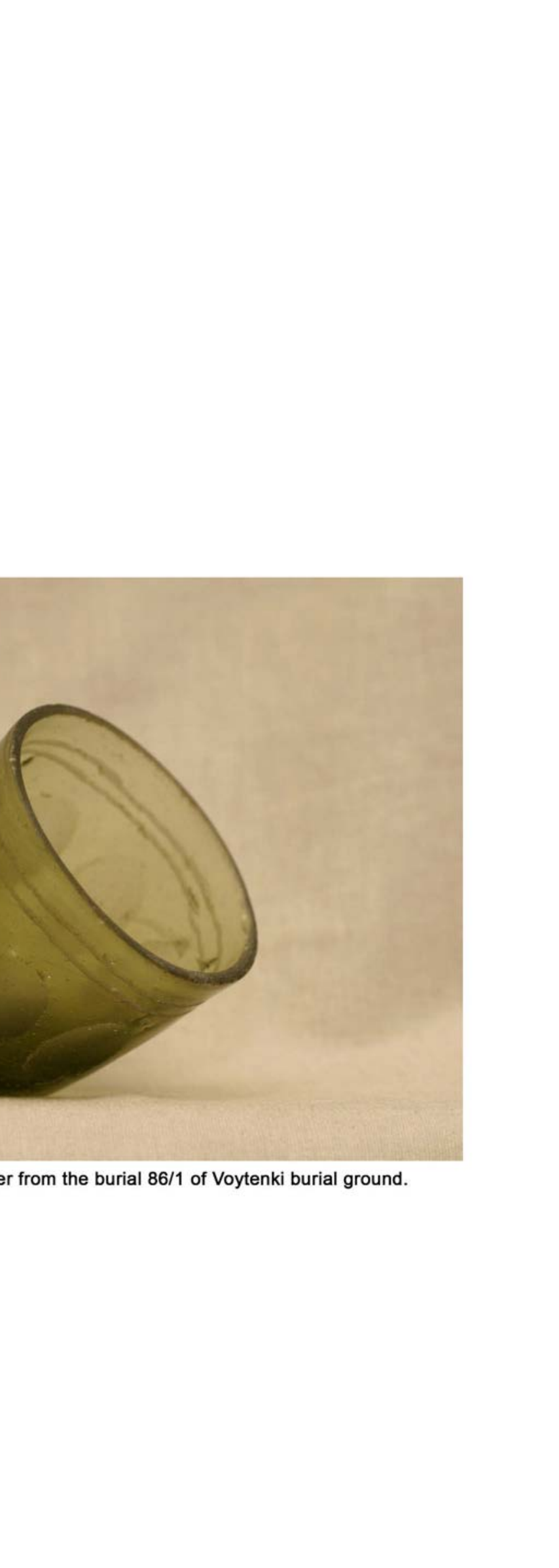



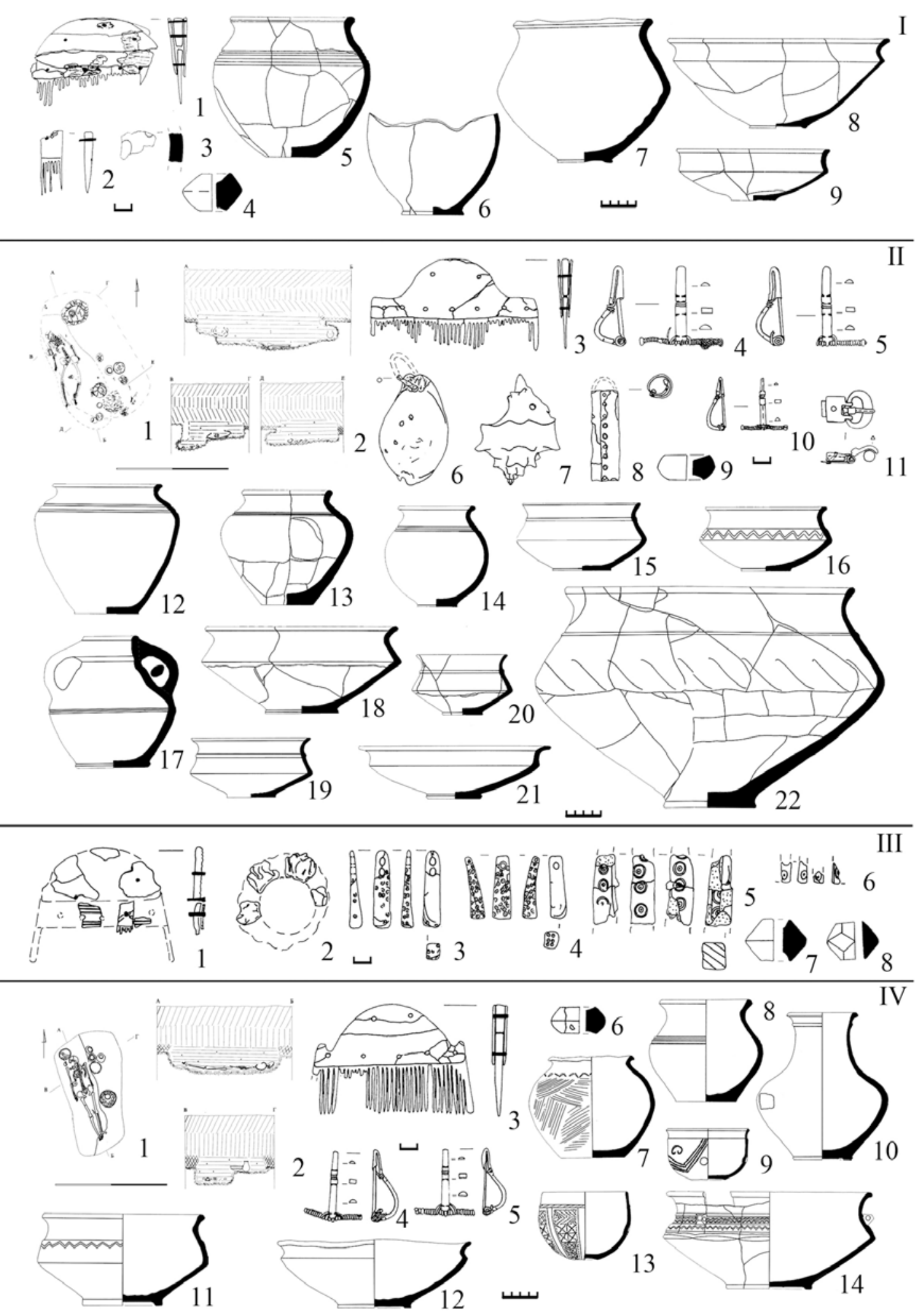

Fig.12. Chernyakhiv Culture: Voytenki burial ground:

I - burial 32: inventory;

II - burial 41 and its inventory;

III - burial 52: inventory;

IV - burial 54 and its inventory. 

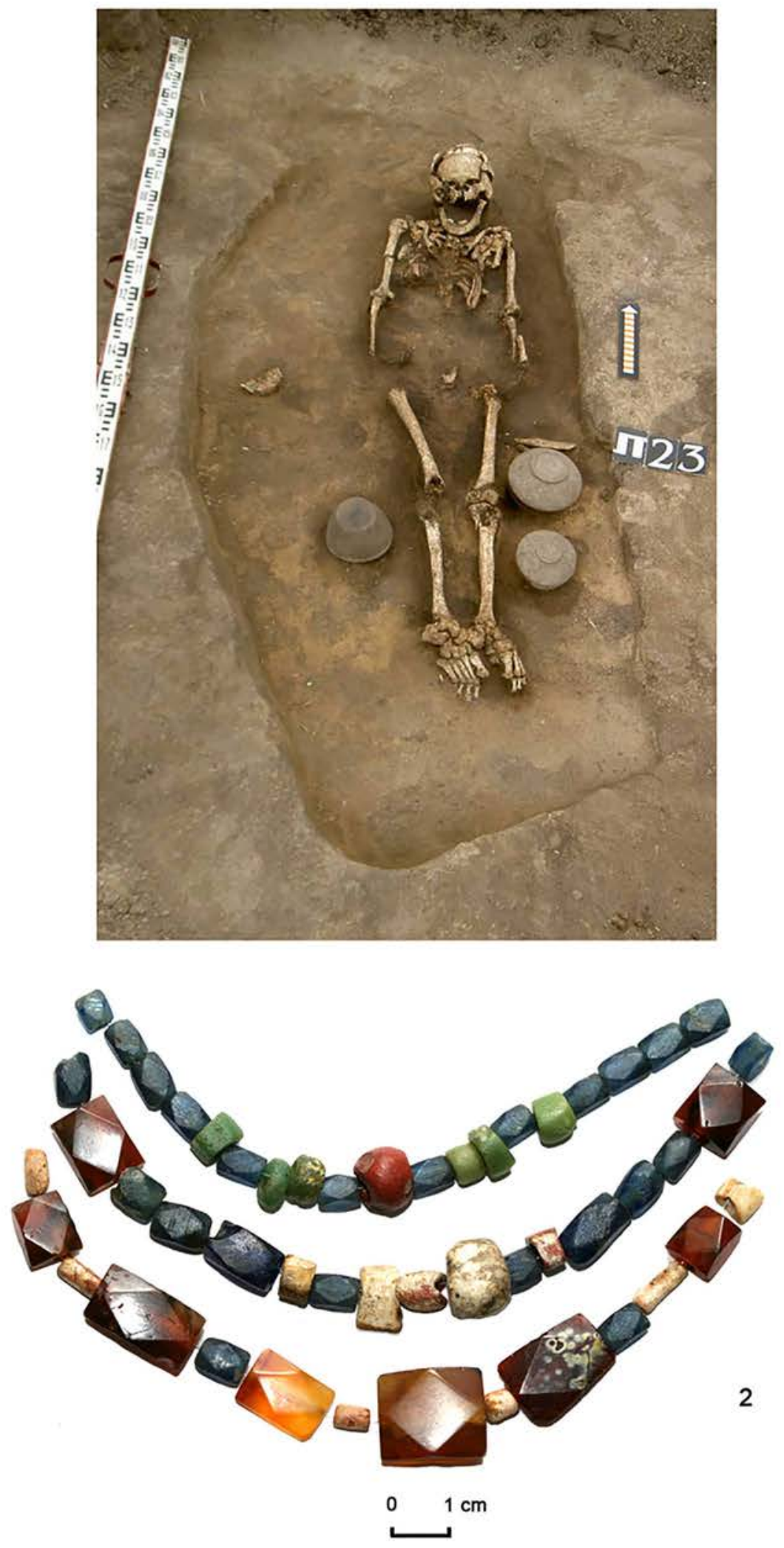

Fig. 14. Chernyakhiv Culture: burial 23 of Voytenki burial ground (1) and its beads (2). 

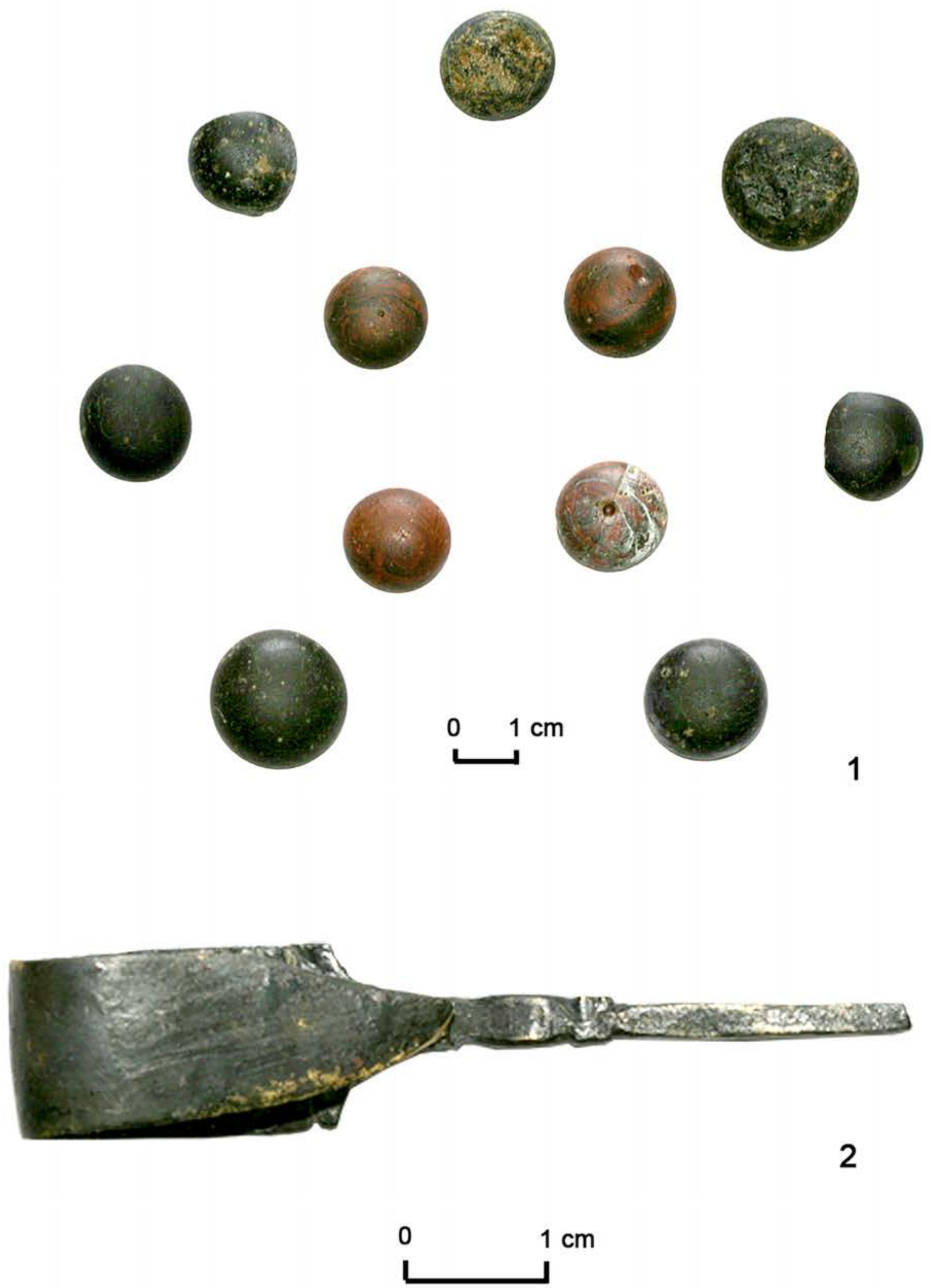

Fig. 15. Chernyakhiv Culture: glass playing tokens (1) and Rome bronze scalpel (2) from cremation burial ground 

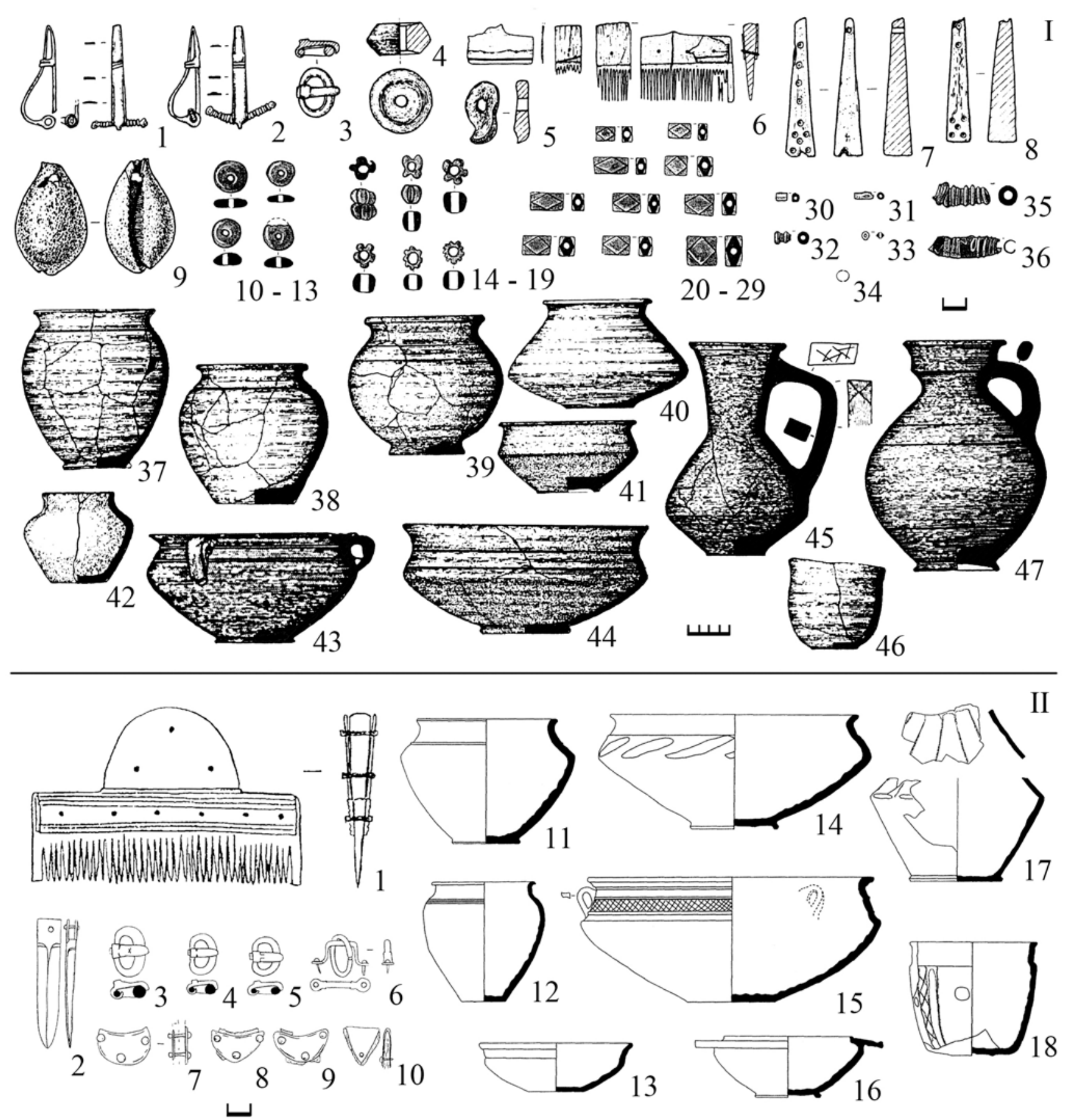

Fig.16. Undermounded burials with Chernyakhiv items:

I - burial 5 of mound 2 near Lavrikovka: 1 - 3 - bronze; 4 - clay; 5, 7 - 9 - bone; 6 - clamshell; 10 - 13 - amber; 14,15 - coral; 16 - 25 - glass; 26 - silver; 27 - 36 - carnelian; 37 - 40 , 42 - 47 pottery; 41 - moulded ceramics (SUPRUNENKO/LIAMKIN/ SIDORENKO 2011, ris. 2 - 5);

II - mound 1 Kantemirovka (RUDYNS'KYI 1930, tabl. I, ris. 4 - 7; tabl. II, ris. 8; OBLOMSKIY 2002, ris. 91). 


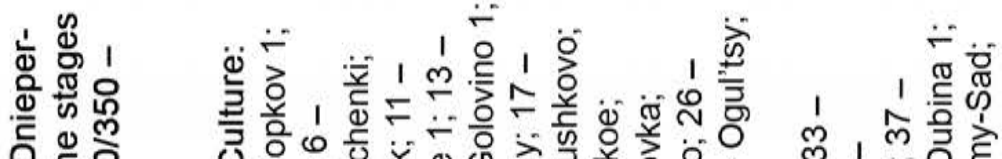

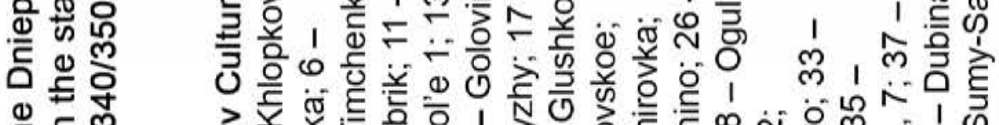

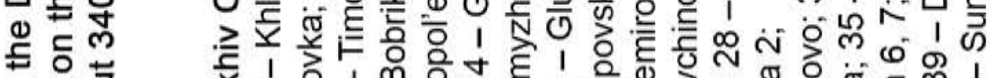

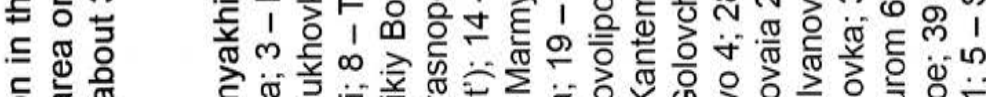

ธ。

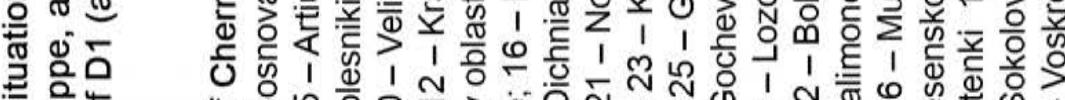

专造范

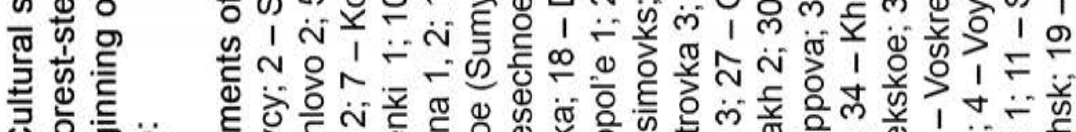

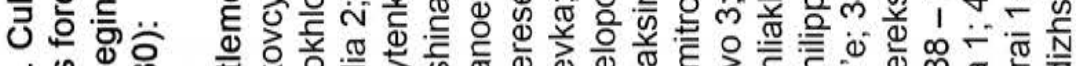

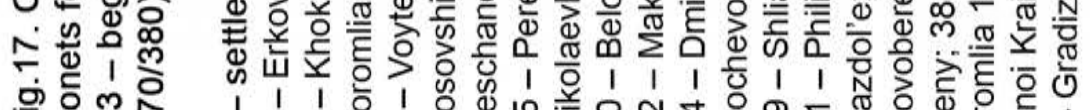

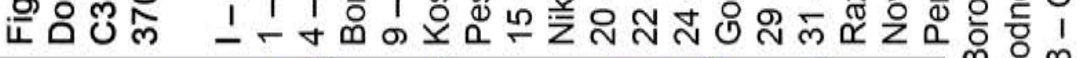

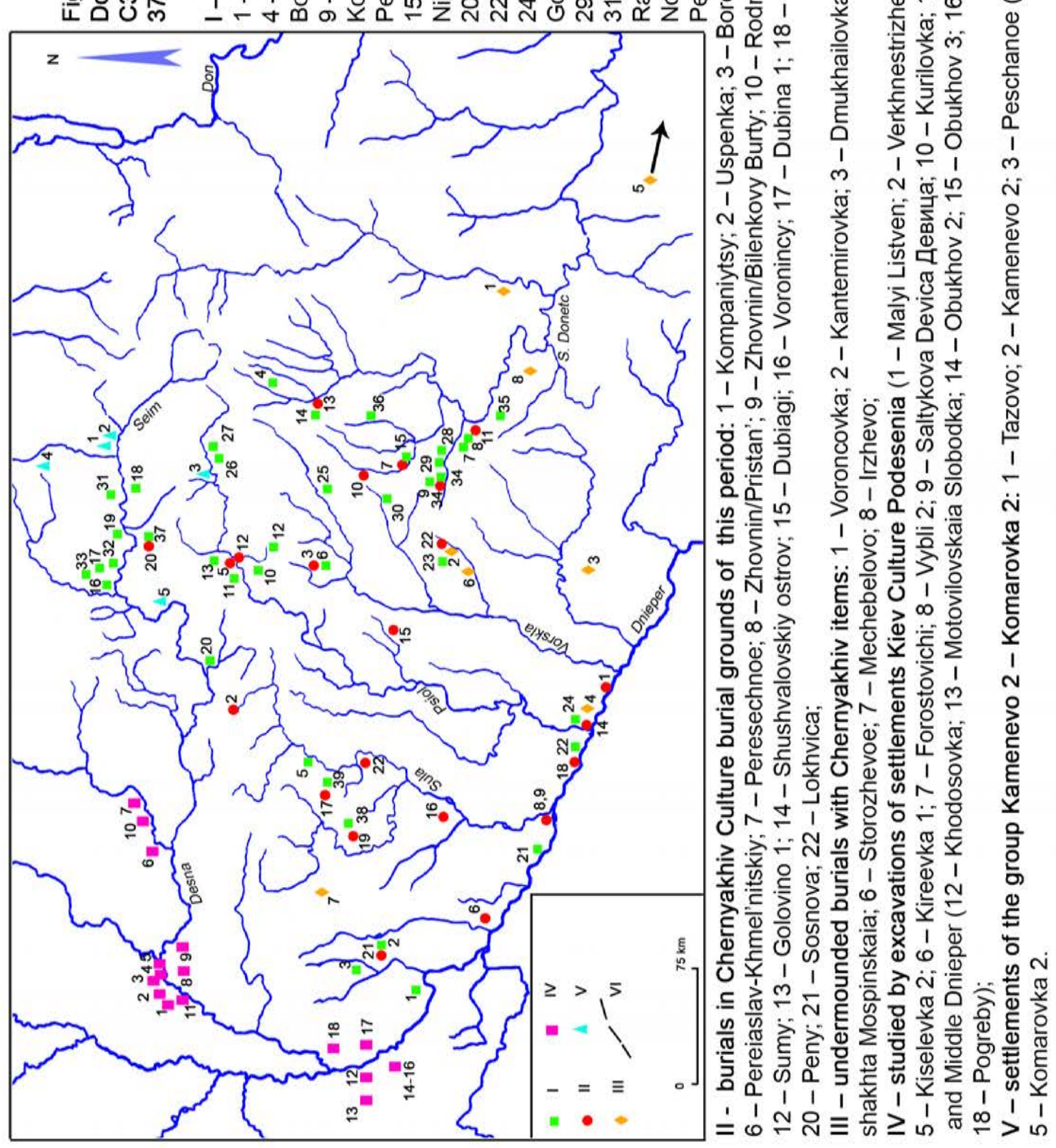



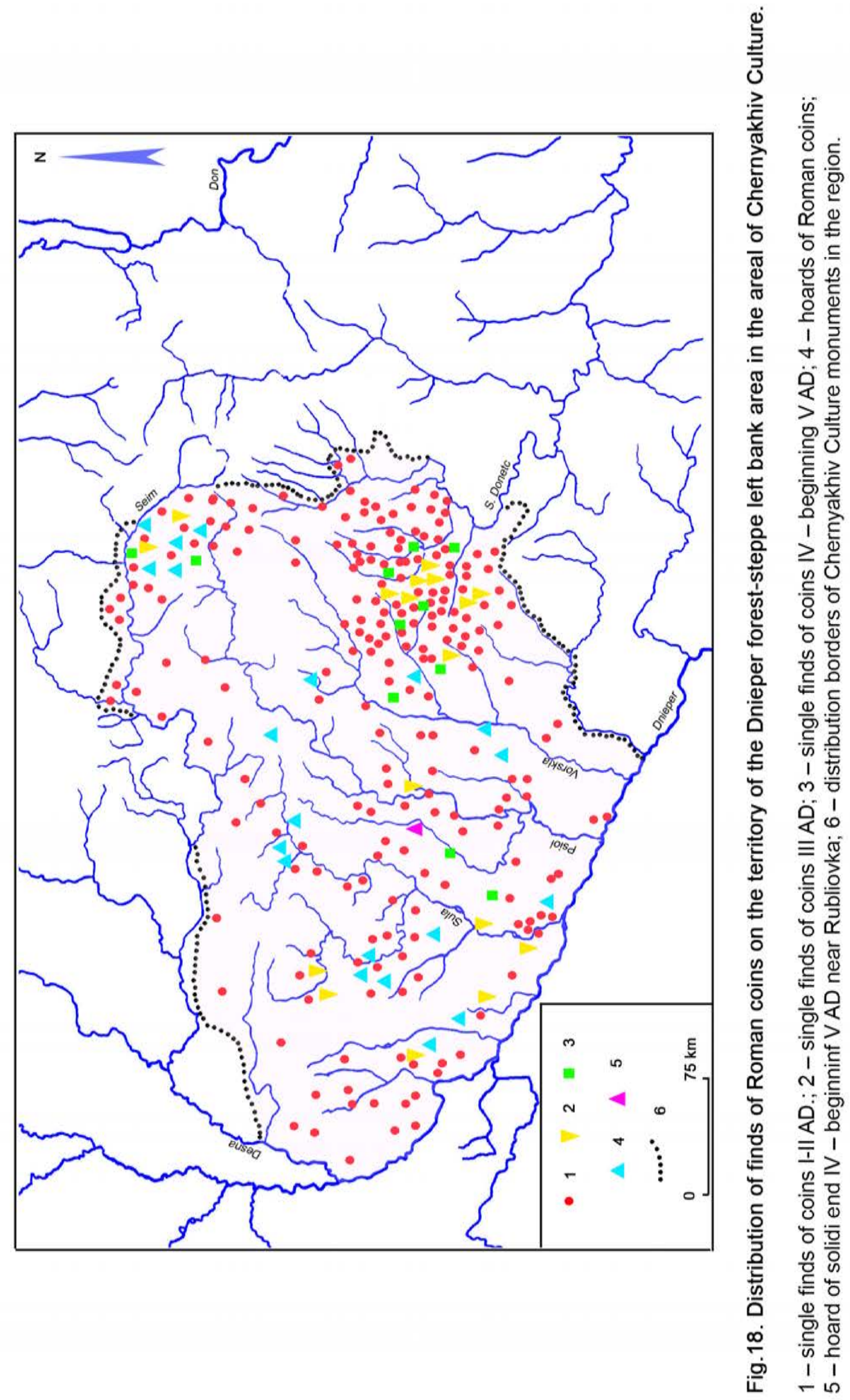

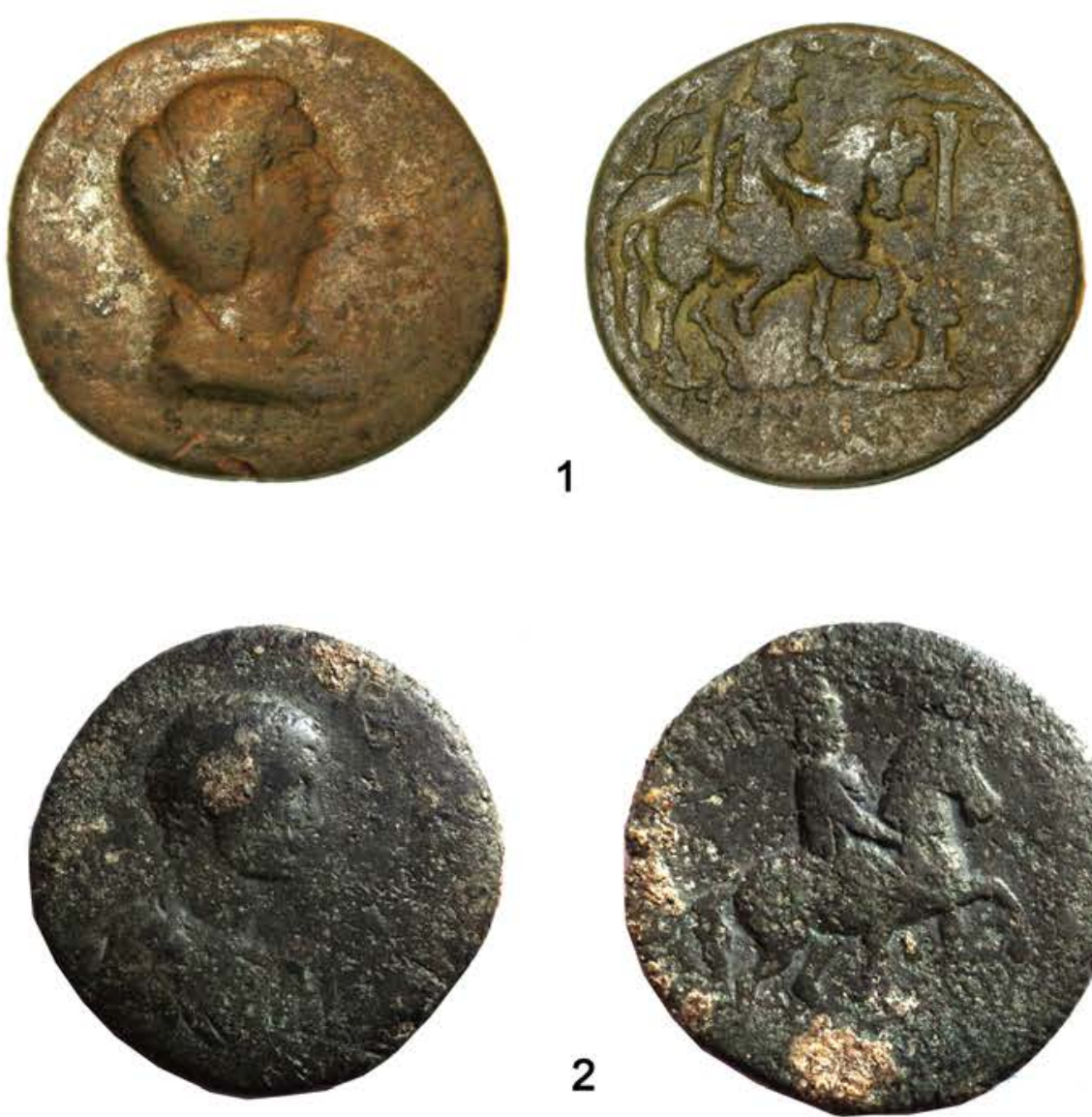

2
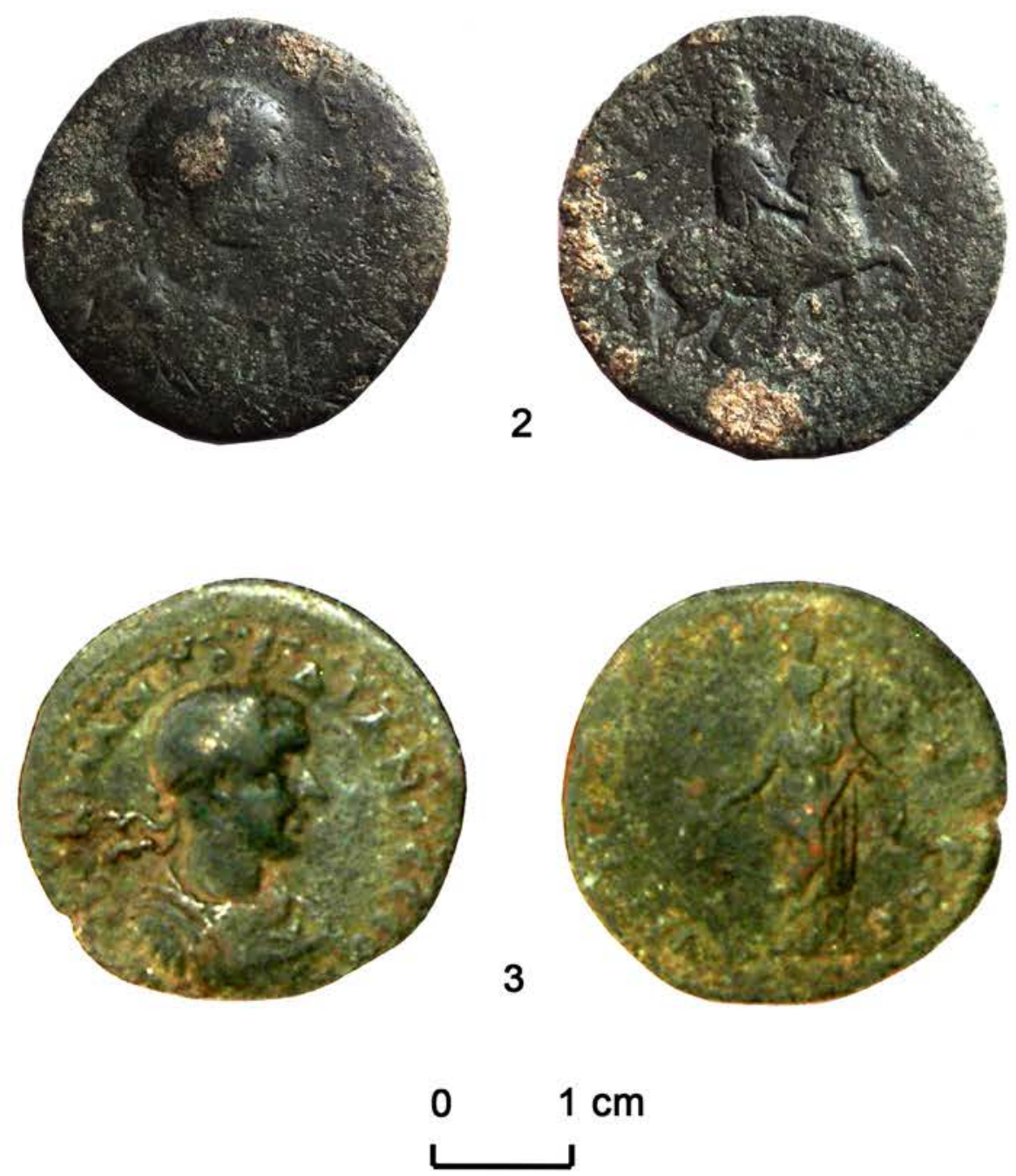

Fig.19. Some finds of Roman coins of autonomic coinage cities of Asia Minor on the territory of the Dnieper forest-steppe left bank area:

1 - Khvorostovo, Kharkov oblast' (Septimius Sever for Julia Domna, Sinope);

2 - Ustimenki, Poltava oblast' (Gordian III, Trapezos); 3 - Khrushovaia Nikitovka, Kharkov oblast' (Gordian III, Trapezos). 

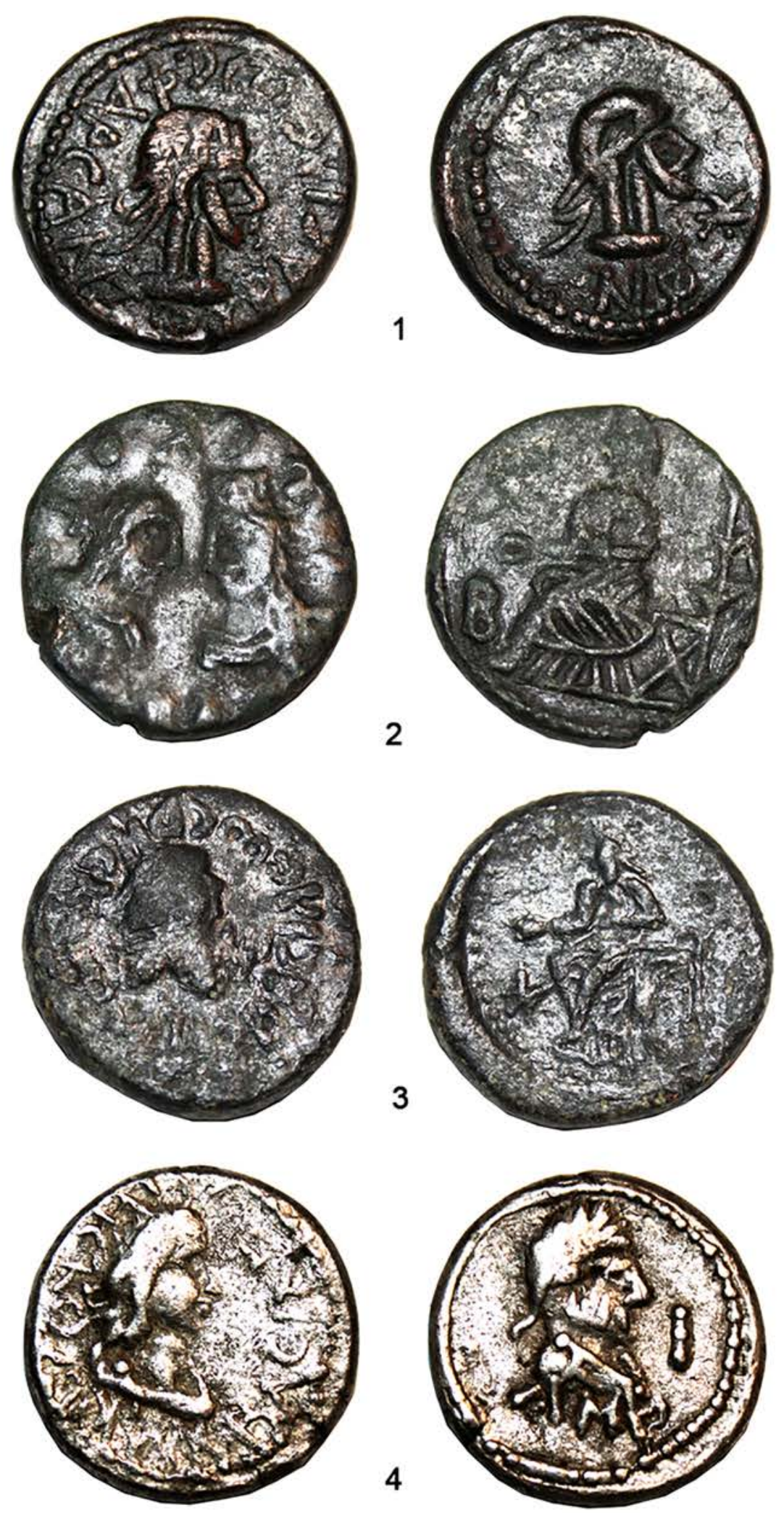

Fig.20. Some finds of Bosporan coins on the territory of the Dnieper forest-steppe left bank area:

1 - Khvorostovo, Kharkov oblast' (Pharsanzes); 2 - Baranovo, Kharkov oblast' (Cotys III); 3 - Dementeevka, Kharkov oblast' (Rhescuporis V); 4 - Khvorostovo, Kharkov oblast' (Rhescuporis V). 